\title{
Grassroots engagement with transition to sustainability: diversity and modes of participation in the international permaculture movement
}

\author{
Rafter Sass Ferguson $^{1}$ and Sarah T. Lovell ${ }^{2}$
}

\begin{abstract}
Grassroots networks and social movements are increasingly regarded as agents of change that can help respond to environmental degradation both by generating novel solutions to existing problems and influencing institutions toward more substantive responses. We examine permaculture, an international movement that, despite its broad international distribution and relatively high public profile, has received little systematic scrutiny in the scientific literature. We attempt to remedy that gap by conducting a broad international (though English-only) survey of 731 permaculture participants, and assessing the socio-demographic characteristics of the movement. The survey examined self-identified roles of permaculture participants and explored the relationships between those roles and socio-demographic factors race, gender, and socioeconomic status. The influence of structural factors on participant roles was examined by including multidimensional national indices development, inequality, and ecosystem vitality, for the 45 countries in the sample. Results showed the participation of women at or above parity (53\%), while participation by race showed a white supermajority $(96 \%)$. Multivariate regression demonstrated that race, gender, and socioeconomic status are shaping participation in distinct ways and that each interact with structural factors. The effects of gender on social roles varied with ecosystem vitality, with women scoring higher than men in countries with high levels of ecosystem vitality, and the reverse where ecosystem vitality was low. The observed effect of race on practice varied with national inequality, such that the scores of respondents of color were equivalent to white respondents in countries with the least inequality, but descended as inequality increased, while whites were unaffected. Different indicators of socioeconomic status depressed and amplified different dimensions of participation. Results point toward a theoretical framework that identifies multiple levels and sites through which socio-demographic factors shape participation in grassroots environmental action, and the outlines of such a framework are discussed.
\end{abstract}

Key Words: diversity; environmental movements; grassroots networks; permaculture

\section{INTRODUCTION}

Increasing concerns about the pace of environmental degradation, including climate change, biodiversity loss, and profligate and unequal consumption of increasingly scarce resources, have been met with incremental responses from large institutions across multiple sectors of society (Beddoe et al. 2009, Grantham 2012, Assadourian et al. 2013). With the substantive failure of governmental regulatory approaches and top-down market-based initiatives to address these issues, increasing attention is being paid to the contributions of actors from outside of large state and nonstate institutions (Ernstson et al. 2008, Bergman et al. 2010, Leach et al. 2012, Seyfang and Haxeltine 2012). Grassroots actors and their aggregates, e.g., networks, communities, and movements, are increasingly looked to as critical agents in the transition to sustainability, helping forestall, mitigate, and adapt to environmental degradation. Scholarship on these issues is spread across multiple disciplines, theories, and terminologies, most saliently in the literature of sustainability transitions, social-ecological systems, and in studies of environmentalism spanning political science, social psychology, and environmental sociology. Emerging scholarship on grassroots innovation networks is helping balance a preponderant focus on top-down technocratic processes in the literature of sustainability transitions (Smith and Stirling 2010, Lawhon and Murphy 2012). At the same time, the focus on grassroots innovation networks bridges a gap between scholarship on sustainability transitions and research on environmentalism, drawing our attention to bottom-up processes of transition that may not look like traditional environmental movements. Our understanding of the forces driving participation in grassroots networks remains limited, however, and there has been little crossover so far with the literature on environmentalism.

Permaculture is an international grassroots network focused on the sustainable design of human settlement (Mollison 1988). Permaculture has a very public profile, with an extensive internet presence and projects on every inhabited continent (Ferguson and Lovell 2014). Although permaculture has historically been isolated from conventional scientific research, recent studies have identified permaculture as a potential contributor to the sustainability of farm practices (Conrad 2014, Ferguson and Lovell 2014, Ingram et al. 2014, Suh 2014a; R. S. Ferguson 2013 unpublished manuscript), as well as ecological literacy and sustainability-relevant behaviors more broadly (Burton 2013, Guitart et al. 2015, Lewis 2014). We address permaculture both as a useful case study to help shed new light on grassroots networks and transition processes, and to provide some foundational assessment of a potentially impactful international network that so far has received little systematic scrutiny.

Based on our extensive review of the literature, no study of the makeup of the network has been published (Ferguson and Lovell 2014). Very little is known about who, in socio-demographic terms, is participating and what forms participation takes. Without previous research on permaculture to draw on, our study is necessarily exploratory in nature, and we cast our analytical net widely in the interest of identifying promising themes and

${ }^{1}$ University of Illinois at Urbana-Champaign, ${ }^{2}$ University of Illinois 
questions for future research. Although the broad spread and substantive content of the permaculture movement suggest potential contributions to sustainability transitions, our ignorance of who is participating limits our ability to assess permaculture's actual and potential impact or to identify barriers to efficacy and growth. The international distribution of permaculture makes it an ideal case for investigating not only the factors shaping participation, but how those factors vary across social and environmental contexts.

\section{Participation at the grassroots: networks and movements}

Researchers and nongovernmental organizations increasingly regard grassroots networks as important sources of innovation and as engines for mobilizing needed resources in support of societal transitions to sustainability, as well as reducing the severity of environmental change (Seyfang 2007, Seyfang and Smith 2007, Ernstson et al. 2008, Bergman et al. 2010, O’Brien 2012, Dellapenna et al. 2013, Pansera and Owen 2014). Grassroots networks do this, broadly, by generating technical and social innovation in response to perceived problems, and by mobilizing around alternative approaches to management and consumption of resources. The appeal of grassroots actors and networks as agents of socio-technical transition is multifold. Grassroots actors may be able to innovate and adapt to changing conditions in ways and at a pace that the inertia of large institutions rarely permits (Seyfang and Smith 2007, Leach et al. 2012). By mobilizing resources in support of preferred technologies, grassroots networks create cultural and economic niches that buffer novel technologies, including forms of social organization, from the market and policy pressures of hostile socio-technical regimes (Smith 2006, Seyfang 2007, Seyfang and Haxeltine 2012). Support for innovation may also become more explicitly and conventionally political, as grassroots networks mobilize political capital to put pressure on existing institutions (Ernstson et al. 2008, Dellapenna et al. 2013).

The characteristics of grassroots networks can also present hazards to effective action. Grassroots efforts can be especially vulnerable to suppression and co-optation by state and business actors (Gerlach 2001, Feola and Nunes 2014, Fressoli et al. 2014). Grassroots networks may be insular and/or exclusive, failing to include stakeholders with critical perspectives on the problem at hand, or failing to extend their influence to relevant constituencies (Ernstson et al. 2008). When grassroots networks focus on local, bottom-up, and project-based solutions, their impact may be constrained by their particularity, limiting their capacity to develop solutions that are generalizable beyond a specific context. Place-based and practical projects are vulnerable to a problem of scalar mismatch, when narrow technical solutions are offered as remedies for problems such as poverty or environmental degradation that are driven by structural rather than technical issues (Smith et al. 2014).

The manifest political dimensions of grassroots networks, including the question of how participation is shaped by sociodemographic and structural factors, have received rather less attention in the literature on innovation and sustainability (Smith and Stirling 2010). There has been little crossover so far between the emerging literature on bottom-up eco-innovation and the expansive literature on participation in environmentalism. This is a critical gap because our ability to assess the capacity of grassroots actors to support meaningful ecological transition hinges on our understanding of the factors that drive and constrain inclusive participation. Whether transition is viewed as a political or technical problem, or both, transitioning to sustainability will require profound changes, and broad and substantive participation across all sectors of society. Such participation is especially important in the case of frontline communities and politically marginalized populations, which are frequently impacted first and most severely by environmental issues even as they are excluded from meaningful democratic participation (Burleson 2010, Conant 2012, Smith and Stirling 2010).

An extensive body of research investigates the ways in which gender, ethnicity, and socioeconomic status, shape engagement with environmentalism, including both formal movement activity and everyday environmentally relevant behaviors. For the purposes of this study we broadly categorize theories of sociodemographic differences in participation into cultural and material explanations. The former look to differences in beliefs, norms, and perceptions, to explain differences in participation across groups, while the latter look to differences in access to material resources. In the case of gender, several studies indicate women are more likely to express concern about environmental issues and to engage in private environmental behaviors, but less likely to engage politically (Mohai 1992). The literature offers both material and cultural explanations for these effects. Biographical availability theory proposes that the socioeconomic and political marginalization of women reduces their access to discretionary time and money, and thereby curtails their capacity to act outside the household (Xiao and McCright 2014). A complementary cultural explanation holds that the gendering of caregiving as women's work encourages women to be especially vigilant for threats to the safety and well-being of the members of their households (Davidson and Freudenburg 1996, MacGregor 2002). Other studies have failed to clearly show these gendered patterns (Tindall et al. 2003), highlighting the need for a better understanding of the ways in which gender effects are mediated by social and structural context. Studies of the agrarian landcare movement in Australia, for example, have shown that groups with high levels of women's participation are more effective than those without (Lockie 1995).

Explanations of gendered participation have parallels in studies of ethnicity and environmentalism. Emerging from research in the U.S., subcultural explanations look to differences in beliefs and values between minority ethnic groups and the white majority to explain patterns in participation (Parker and McDonough 1999). This body of research offers few definitive answers, however, and many contradictory findings. Some scholars link this confusion to the wide variety of definitions, framings, and scales being deployed in these studies, suggesting the unsurprising irony that differing beliefs and values are embedded in the design of research intended to address differences in beliefs and values (Johnson et al. 2004, Li and Wehr 2007). Barriers to participation theories integrate aspects of cultural and material explanation (Adams 1992, Parker and McDonough 1999). Barriers theories assume that environmental values are similar across groups, and that differences in participation are driven by histories of 
oppression and exclusion, bias within white-dominated environmental movements, and feelings of powerlessness among marginalized groups. Barriers theories thereby shift attention to the culture of majority-white environmentalism as a force excluding or limiting nonwhite participation (Kalof et al. 2002).

Drivers of participation do not operate strictly at the level of individual socio-demographic factors. Broader social, politicaleconomic, and environmental context also shape engagement with environmental issues in ways that invoke cultural and material explanations (Dietz et al. 1998). Environmental concern has long been identified as a facet of "postmaterialist" values and thereby a luxury of the industrialized nations (Kemmelmeier et al. 2002) who are themselves the lead contributors to global environmental crises. This view is the subject of vigorous debate, with some studies showing opposite effects, i.e., an inverse relationship between environmental concern and national affluence (Gelissen 2007, Dunlap and York 2008). The "objective problems-subjective values" theory attempts to reconcile seemingly contradictory findings by proposing that environmental concern in the highly developed nations is driven by values, while that in the less-developed nations is driven by direct experience of environmental degradation (Brechin 1999). We must assume that individual- and structural-level forces interact to drive engagement. To our knowledge no research has addressed the effects of cross-scale interactions on engagement (cf. Nawrotzki 2012, which examines the influence of such cross-scale interactions on a single measure of environmental concern). Examination of cross-scale interactions holds the potential to bolster and clarify both individual-level and structural effects. For example, material barriers to participation should have greater effects in countries with greater levels of distributional inequality. Cultural (and cross-cultural) effects that presume environmental context, such as women's socialized vigilance for threats to the household, should have stronger effects where environmental degradation is greater.

Although it is important to identify the ways in socioeconomic and cultural forces suppress diverse participation (Verba et al. 1995), apparent differences in level of engagement may obscure qualitative differences in style of engagement. The participation of members of marginalized communities can pass unrecognized if research questions are informed only by the environmentalism of elites. Research on innovation for sustainability tends to direct our attention to top-down processes of policy and technocratic management (Seyfang and Smith 2007, Bergman et al. 2010) rather than bottom-up innovation and mobilization. Despite evidence to the contrary, the literature often situates individuals and communities with little access to resources largely as markets for innovation flowing from the top down, rather than sources of innovation that can benefit not only themselves but also the wider world (Pansera and Owen 2014).

Research on environmentalism does distinguish between public/ political and private/personal engagement forms of engagement (Mohai 1992, Coffé and Bolzendahl, 2010). Although valuable, this dichotomy still threatens to obscure or undervalue forms of engagement that do not look like conventional movement politics (Lockie 1995, Lewis 2014). Recent studies have highlighted the complex relationship between race, gender, and socioeconomic status, and nonmovement forms of engagement including land- use planning (Villamor et al. 2014), relational activism, which might in another context be called social innovation (O'Shaughnessy and Kennedy 2010), and eco-innovation (Pansera and Owen 2014). This quantitative survey-based research is complemented and challenged by qualitative research that takes the engagement of women and people of color as a starting point and explores the ways in which identity shapes participation (Taylor 1997, Einwohner et al. 2000, Culley and Angelique 2003, Rainey and Johnson 2009, Bell and Braun 2010). Taken together these studies suggest that as we identify the forces of exclusion shaping forms of action associated with elites, we should also expand our conceptions of participation to encompass multiple dimensions of bottom-up engagement.

\section{Objectives}

In this study we direct these questions about drivers of bottomup participation in sustainability transitions to an examination of the permaculture movement. In doing so we address several intersecting gaps in the scientific literature. The first is highlighted by the emerging literature on grassroots innovation, which has brought attention to the importance of extra-institutional actors and networks for processes of sustainability transition. This literature has so far, however, paid little attention to the sociodemographic constraints on participation in these networks. The influence of socio-demographic factors on the dynamics of inclusion and participation is critical for understanding the capacity of grassroots networks in transition to sustainability.

The second gap is the lack of any systematic examination of the permaculture movement. As a network and a set of ideas, permaculture appears to have something to offer to sustainability transition, but our ignorance of who is participating, and how, inhibits our ability to assess its potential and identify barriers to efficacy and growth. This study attempts to remedy that gap by conducting a broad international, though English-only, survey of permaculture participants and analyzing the socio-demographic characteristics of the network. The analysis explores the relationships between multiple participant roles identified by respondents, as well as the relationships between those roles and individual and structural forces. In investigating the influence of socio-demography on dimensions of participation in permaculture, this project also extends the existing literature of personal, socioeconomic, and structural influences on grassroots environmentalism, with an emphasis on exploring the interactions between structural and individual factors.

Our objectives were the following: (1) provide a foundational description of permaculture as a grassroots innovation network; (2) describe the socio-demography of participants; (3) identify the ways in which personal, social, and structural factors shape the roles played by participants, with special attention to gender, race, and socioeconomic factors at the individual and structural level; and (4) identify questions for future investigation. This exploratory research is driven by the overarching questions: Who is participating in permaculture? What roles are they playing? How do socio-demographic factors shape participant roles?

\section{Permaculture}

A recent systematic review organizes analysis around four strata, assessing permaculture as design system, best practices framework, worldview, and movement (Ferguson and Lovell 2014). Across these strata, permaculture offers a distinctive 
perspective on social-ecological transition, with key principles that parallel or prefigure themes in sustainability-oriented scholarship, such as landscape multifunctionality, ecosystem mimicry, ecoagriculture, intervention ecology, and adaptive management (Nudds 1999, Blann et al. 2003, Folke et al. 2003, Scherr and McNeely 2008, Lefroy 2009, Hobbs et al. 2011, Ferguson and Lovell 2014). It is a direct antecedent to the international Transition Town movement that is receiving significant scholarly attention for its decentralized and populist approach to grassroots transition processes (e.g., Feola and Nunes 2014).

Permaculture's central concept is that humanity can reduce or replace energy and pollution-intensive industrial technologies, especially in agriculture, through intensive use of biological resources and thoughtful, holistic, design, patterned after wild ecosystems (Holmgren 2002). Founded in the late 1970s by white Australians Bill Mollison and David Holmgren, permaculture's broad geographic spread today is largely because of Mollison and a relatively small cohort of teachers, who spent the decades following permaculture's founding teaching internationally at an ambitious pace (Dawborn and Smith 2011). The permaculture movement today consists of a loosely affiliated network of individuals and projects, connected through permaculture courses and workshops, online forums, and local projects, as well as through and regional, national, and international convergences (Dawborn and Smith 2011, Ferguson and Lovell 2014). Groups generally display a low level of institutionalization, and projects encompass a wide variety of functions, commonly including community gardens, campus greening initiatives, educational efforts, and less commonly, demonstration and/or research sites, periodicals, and farming-focused education and support efforts. Although permaculture has a strong focus on productive landscapes, it does not appear to be a generally rural/agrarian phenomenon. The concerns of permaculture's literature and web presence are spread across the urban-rural gradient, and discussion of production have focused primarily on home- and market-garden scale.

Transition requires not only socio-technical innovation, but also the narratives and values that motivate adoption and advocacy (Dellapenna et al. 2013, Philippe and Bansal 2013, Fressoli et al. 2014, Paschen and Ison 2014). Though popular discussions of permaculture often focus on questions of practice and technique, the contributions of such grassroots networks to sustainability transitions may be through the worldview they disseminate (Kemmelmeier et al. 2002, McFarlane and Boxall 2003). The permaculture worldview incorporates a theory of humanenvironment relations that positions humans as ecosystem managers, highlighting the potential for holistic design and management to meet human needs while increasing ecosystem health (Toensmeier and Bates 2013). Like contemporary theories of social-ecological systems (Gunderson and Holling 2002, Berkes et al. 2003), this notion contradicts both traditional, preservation-oriented conservation, and growth-oriented development, each of which invokes a fundamental contradiction between human well-being and ecosystem health (Pálsson 1996, Strongman 2012).

It is likely that participants' level of engagement (Parker and McDonough 1999) with permaculture is driven by an experience of empowerment (Smith 2002). The "simple solutions populism" of permaculture (Ferguson and Lovell 2014:267) suggests that the best responses to global crises can be implemented immediately with readily accessible materials and skills. As a theory of change, simple solutions populism shifts the perceived locus of control over environmental crises toward the individual (Hines et al. 1987) and ameliorates the inverse relationship between the scale of environmental problems and individuals' sense of efficacy (Uzzell 2000).

The worldview of permaculture is reflected in a model of change that mostly spurns systematic engagement with existing institutions in favor of direct intervention into the means of subsistence, reintegrating production and resource management under the stewardship of local individuals and communities (Dawborn and Smith 2011). This strategy for social transformation seeks to rework human-environment relations from the ground up and avoid the "long march through the institutions" (Cornils 1998). The flat network structure that accompanies this mode of action appears to be a conscious strategy to avoid the twin dangers of co-optation and outright suppression to which grassroots efforts are vulnerable (Mollison 1997, Gerlach 2001, Feola and Nunes 2014). This model has met with some success, as evidenced by its international distribution and positive influence on urban land use, horticultural and agricultural practices, and other sustainability-relevant behaviors across contexts (Yuen et al. 2001, Soares 2003, Ventura and Andrade 2011, Burton 2013, Ferguson 2013b, Guitart et al. 2015, Conrad 2014, Lewis 2014, Suh 2014a,b).

The evident successes of the permaculture network are balanced by problematic assumptions and implications that evoke the hazards of insularity, exclusivity, particularity, and scale mismatch to which grassroots networks are prone. The emphasis on individual responsibility, and the proposed abandonment of existing civic and civil institutions, provide uneasy parallels with neoliberalism, the dominant political-economic ideology of our time (McCarthy and Prudham 2004, Guthman 2008). Like other versions of localism and voluntarism, these aspects of permaculture threaten to engender a depoliticized naiveté concerning the scale of responses needed to address global and regional crises (Mohan and Stokke 2000, Allen and Guthman 2006).

Especially salient for this study is the notion, entrenched in permaculture thinking, that a lack of formal hierarchies within the network ensures equitable access and democratic governance:

As permaculture is open to new information, and to every person, it results in highly individual expressions of projects everywhere. As we are largely self-funded, we cost very little, and are not controlled by outside monies. Thus we are not subject to any external controls beyond our own ethics, or our own will to act. As we are a nonhierarchical network joined only by volunteer [sic] or the user-pays principle, we have no internal status differences, and we relate as equals. As we never need to vote, we are democratic; each acts as they see beneficial. (Mollison 1997:30-31).

In dismissing the possibility of constraints on participation other than individual interest, Mollison encourages a "demography 
blind" perspective that ignores the forces of privilege and exclusion embedded in race, gender, and class relationships (Bonilla-Silva 2009). The conflation of a lack of formal hierarchy with the absence of hierarchy in general is not unique to permaculture, and has been the subject of critique since the years of permaculture's founding, first in the context of the emerging second-wave feminist movement (Freeman 2013), and most recently in criticism directed specifically at permaculture's sibling movement Transition Towns (Trapese Collective 2008). An alternate view is that socio-demographic constraints on diverse participation can only be remedied through programmatic mobilization of resources and strategic policy initiatives requiring some level of institutionalization. Formal and bureaucratic hierarchies often constitute pernicious barriers to transition, but these effects can be ameliorated through participatory democratic structures and processes (Fung and Wright 2001, Menegat 2002). Informal hierarchies of rank and privilege, on the other hand, lack such concrete points of leverage and are often invisible to their beneficiaries (Sue 2004).

Low levels of institutionalization may also constrain capacity for program development, systematic tracking of outcomes, and engagement with potential allies. Recent research suggests that the permaculture network in the UK is vulnerable to insularity, and thereby to a lack of capacity to influence relevant institutions and communities (Ingram et al. 2014).

We primarily use the term grassroots network to describe permaculture, rather than the more specific "grassroots innovation network" or "global action network." We use this term in the interest of simplicity, to situate our investigation in relation to the literature on sustainability transitions, and because it better conveys the generally low levels of institutionalization associated with permaculture. We will also use the term movement to reflect the permaculture literature itself, and when it serves clarity and readability.

\section{METHODS}

\section{Data collection}

We administered the survey using the online service Surveymonkey from July to October. The survey was only available in English. We solicited respondents through a variety of electronic and social media, including regional, national, and international permaculture-related email lists and online forums, through permaculture interest groups on social media, and through the researcher's website. We also asked respondents to refer the survey within their own networks. We invited people who "participated in permaculture in any way" to respond, and the survey was restricted to respondents 18 years of age and older. A total of 1055 respondents began the survey. By virtue of web access and language, our sample excludes important sectors of participants in permaculture, and this exploratory study pertains only to that sector of the permaculture network with web access and facility in English.

To screen out respondents with no connection to permaculture, only respondents who first indicated involvement with permaculture were given access to the survey. We additionally removed respondents who did not select any roles (see below) and those who explicitly indicated ignorance of permaculture in openended responses. In the data cleaning phase we eliminated responses with less than $70 \%$ completion and responses without geographical location information. These screening steps left 731 responses for analysis. Results are concentrated in the United States $(59 \%)$, Australia (15\%), Canada (8\%), and the United Kingdom ( $5 \%)$. The rest of the responses were distributed among 42 countries, with 1-9 responses per country.

In addition to standard socio-demographic questions, the survey contained sections addressing roles played by participants, participation in network activities, the influence of permaculture on sustainability-relevant lifestyle behaviors, experiences in permaculture education, prior understanding of permaculture, and understanding gained from exposure to permaculture on a number of broad social and ecological themes. The survey also contained a section addressing levels of participation in permaculture projects and institutions, civic institutions, and social movement activities, and the level of integration of permaculture with the latter two categories of activity. The survey included separate sections on professional permaculture work in design, farming (and other agricultural/horticultural production occupations), and education. Only socio-demographic data and roles are assessed in this paper.

To assess participant roles, we asked respondents to check all applicable terms in a list following the question "What role have you played in permaculture?" Choices consisted of community member, activist, teacher, organizer, professional, practitioner, designer, consultant, and student. The role categories were arrived at based on expert knowledge, grounded in extensive review of the literature and a decade of personal experience in the permaculture network.

\section{Data analysis}

We carried out data analysis in four stages: cleaning and preparation, descriptive analysis, factor analysis, and multilevel modeling. We carried out preliminary cleaning and processing of data, including regularization of open-ended questions and geocoding, using the spreadsheet application Numbers (v. 2.3) and Google Refine (v. 2.5, now OpenRefine). We performed subsequent analyses in the R software environment (v 3.2.0).

Explanatory variables were divided into personal factors, socioeconomic status indicators, and structural factors. Personal factors included gender (M/F/Other), age, and race/ethnicity (white/Caucasian, Native American, Hispanic, Asian/Pacific Islander, black/African-American). Socioeconomic status indicators included highest level of education completed, relative income (annual income as a proportion of the national median annual income), and residential status (rent/own/live with family/ other).

Structural factors consisted of national-level indices drawn from secondary sources, including measures of overall human development, socioeconomic inequality, and ecosystem vitality (Fig. 1). The Human Development Index (HDI) is a composite index created by the United Nations Development Programme, intended as a multidimensional measure of human well-being and a substitute for Gross Domestic Product. It includes measures of life expectancy, education, and gross national income per capita (Sen and Arnand 1994). HDI scores were available for all countries except Japan $(\mathrm{N}=2)$ and Saudi Arabia $(\mathrm{N}=1)$. 
Fig. 1. Structural variables: national indices of development, inequality, and ecosystem vitality across 45 countries. Distribution of scores on three national-level indices for the 45 countries in the sample. The four top-responding countries are shown in color, and the remaining 42 countries are in grey. The indices are each multidimensional, and dervied from the following sources. Human Development Index (HDI) is compiled by United Nations Development Programme (UNDP), Inequality is the penalty to HDI calculated as part of the Inequality-Adjusted Human Development Index (also compiled by UNDP), and Ecosystem Vitality is part of the Environmental Performance Index complied by Yale University and Columbia University. Although the four top-responding countries respresent the bulk of the responses, they only represent a small portion of the range of national-level conditions represented in the sample.

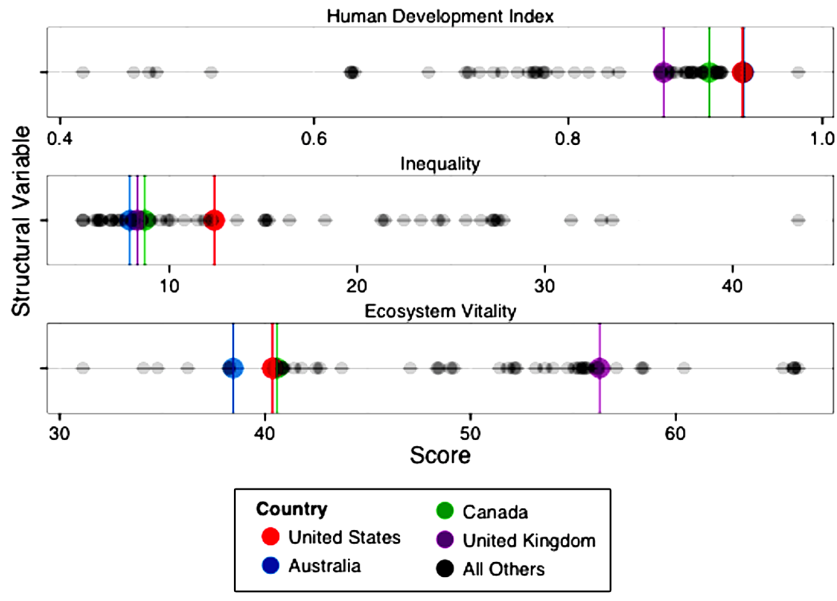

The Inequality-Adjusted Human Development Index (IAHDI) calculates a penalty for each of the dimensions of the HDI based on distributional inequality (Hicks 1997, Alkire and Foster 2010). We used the aggregated penalty (expressed as the percent loss to HDI) as an index of national-level inequality. Of the countries in the sample for which HDI scores were available, i.e., excepting Saudi Arabia and Japan, the inequality score was available for all except South Africa $(\mathrm{N}=8)$.

To investigate the effect of environmental quality we used the Ecosystem Vitality (EV) component of the Environmental Performance Index generated by the Yale Center for Environmental Law \& Policy as a predictor variable. The Ecosystem Vitality index includes dimensions of air quality, water resources, biodiversity and habitat, natural resources, and sustainable energy (Emerson et al. 2010). This index was available for all countries represented in the sample.

\section{Imputation of missing data}

After assessing descriptive statistics and prior to model fitting, we imputed missing values in the predictor variables to retain information in cases with complete sets of response variables and partial sets of socio-demographic predictors. Multivariate imputation with chained equations, using a random forest prediction algorithm, was performed with the mice function in the R package of the same name (van Buuren and GroothuisOudshoorn 2011). A small number of missing structural variables were imputed with the same approach, but calculated separately and prior to personal variables, using 50 national-level variables drawn from the combined datasets of the Inequality-Adjusted Human Development Index and the Environmental Performance Index as predictors for imputed values. Insufficient data were available to justify the imputation of otherwise national-level indices for the territories of Bermuda $(\mathrm{N}=3)$ and Puerto Rico $(\mathrm{N}=1)$, and these responses were therefore left out of the model.

\section{Factor analysis}

We then performed exploratory factor analysis on the nine role variables, with the goals of identifying relationships between roles and extracting a smaller number of new variables, thereby reducing dimensionality. We used the fa.poly function from the psych package, which computes tetrachoric correlations and is therefore suitable for use in factor analysis of binary data such as the role variables (Fox 2009, Revelle 2012). We assessed factor adequacy with the Kaiser-Meyer-Olkin (KMO) measure of sampling adequacy, and extracted factor scores for each using the ten-Berge method.

\section{Model fitting}

We then fitted a multivariate multilevel model using the extracted variables from the factor analysis as response variables and sociodemographic and structural variables as predictors. Prior to model fitting we confirmed the absence of multicollinearity for all continuous predictor variables. We aggregated groups within categorical variables to produce binary variables, with the intent of reducing model complexity, using a heuristic of contrasting traditional power-holding groups with historically marginalized groups, despite the real differences in kind and scope of marginalization that these groups experience. We aggregated ethnicities other than white/Caucasian (Asian or Pacific Islander, Hispanic, black/African American, and Native) under the category People of Color (POC). We will refer to the simplified variable as race, and continue to refer to the original variable as ethnicity. We merged the gender categories female and other on the grounds of sharing marginal status in patriarchal societies. We assume that the observed effects of the simplified Female/ Other category are driven by the supermajority of femaleidentified respondents, so we will refer to that category as women and/or female when discussing the model. We aggregated residential status into two categories, contrasting homeowner and "other" residential status, with the latter category including renting, living with family, and other. We specified interaction terms between select national-level structural variables and individual-level socio-demographic variables: between the environmental index and gender, and between the inequality index and gender, race, and income.

The survey, although only available in English, received responses from both anglophone and nonanglophone countries. To control for any effects of the relationship between the language of the survey and national language, we included a binary variable indicating whether the national language(s) of respondents' country of residence included English.

Because our data consists of individuals nested within countries, with variables at both levels, traditional regression would violate assumptions of independence. Regression methods that are 
appropriate for nested data are referred to by multiple names, including multilevel modeling (MLM), mixed effect modeling, random coefficient modeling, and hierarchical modeling. MLM approaches are increasingly chosen for their flexibility and power. Their flexibility stems from their ability to accommodate unbalanced data, and their power because they "borrow strength" across group, estimating parameters through partial pooling of variation (Gelman et al. 2004).

We selected a Bayesian modeling strategy to fit our model for several reasons. Practically speaking, few statistical packages can accommodate multilevel multivariate regression models. In the $\mathrm{R}$ environment, the most mature and flexible function for fitting multivariate MLMs is MCMCglmm, which is Bayesian in approach (Hadfield 2010). Bayesian MLMs have been used effectively in cross-national studies of attitudes toward, though not engagement with, environmentalism (Nawrotzki 2012, Mostafa 2013). The Bayesian approach is also theoretically suitable. Model fitting in a Bayesian framework does not rely on assumptions about sampling distributions and allows for probabilistic examination of model parameters based on posterior distributions. It therefore naturally lends itself to modelbased inference, which is more appropriate for our nonprobability sample than the more conventional design-based inference (Koch and Gillings 2004). Bayesian model fitting follows the following steps: (1) Prior knowledge is used to assign distributional assumptions (priors) to model parameters. (2) A likelihood function is calculated based on the priors and the data. (3) Priors are multiplied by the likelihood function to produce a posterior distribution of parameter values. (4) Posterior distributions are then iteratively sampled and updated using Marcov Chain Monte Carlo (MCMC) simulation. With sufficient sample size and/or the specification of uninformative priors, the MCMC algorithm will produce estimates of model parameters comparable to frequentist approaches, as the data overwhelms the influence of the priors (e.g., Mostafa 2013).

Using the MCMCglmm package, we followed the standard practice of using uninformative priors, specifying an inverseWishart distribution for variances with a mean of zero and low degree of belief. Following Hadfield (2010), we fit a parameter expanded model, incorporating redundant working parameters that are not identified in the likelihood function, to improve mixing of the sampling chains and speed convergence. We ran the final model for 500,000 iterations, discarding the first 60,000 draws as burn-in to reduce the influence of starting values, and retaining every 80 th draw thereafter to protect against autocorrelation within the chains. These conditions produced an effective sample size of at least 4790 for all parameters of interest. We verified low levels of autocorrelation within chains $(<0.04$ at any lag; Congdon 2014). To assess convergence we visually inspected trace plots and kernel density plots of the simulation draws for all parameters, and verified that trace plots appeared as random noise and kernel density plots appeared approximately normal. We used visual posterior predictive checks to assess model fit, confirming that all observations fell within the $95 \%$ credibility interval of the mean of the posterior predictive distribution (Gelman et al. 2004).
Model-based inference for exploratory research

In an exploratory context, with no systematic knowledge of the target population, and a convenience sample generated by the uncontrolled web-based distribution of the survey instrument, the most appropriate approach to inference is model-based rather than design-based (Sterba 2009). Conventional design-based inference relies on randomized sampling from a finite population to reduce sampling bias and support inferences about the population. Model-based inference is a complementary approach that focuses on the relationship between variables in the model rather the relationship between the sample and the population. It is often used for web-based research and other scenarios when randomized samples are not feasible (Schonlau et al. 2002, Anderson 2008, Bethlehem and Biffignandi 2011, Clarke 2011).

This study is relevant to a specific sector of permaculture participants, those with web access and facility with English. This sector warrants investigation in its own right, and we must also note that those excluded from our sample by technology or language include important sectors of the permaculture network, in the developing world particularly, including smallholder farmers and other subsistence producers (Terui 2000, Meigs 2004, Felix-Romero 2010, Conrad 2014).

\section{RESULTS}

\section{Description}

Personal variables

Personal socio-demographic variables included gender, race/ ethnicity, and age (Table 1). Gender responses across all 731 respondents were 389 female, 328 male, and 14 other. Female respondents were the largest category in most groupings, including the four countries with 38 responses (USA, Australia, Canada, and UK, $\mathrm{N}=643$ ). Reported age of respondents had an overall median of 40 .

Racial/ethnic identification among respondents was overwhelmingly white/Caucasian (661), followed by Hispanic (16), Asian or Pacific Islander (10), black/African American (9), Native American (6), and 29 nonresponses. Of the top four responding countries, responses from Canada were the most diverse, with most numerous responses from white/Caucasian (56), followed by Asian or Pacific Islander (2), and black/African-American (1), and Native American (1). The least diverse set of responses were from the UK, with no respondents identifying as other than white/ Caucasian. Responses from outside the top responding countries were more diverse, though still showing a super-majority of white/ Caucasian respondents (74), followed by Hispanic (8), Asian or Pacific Islander (3), and 3 nonresponses. In Figure 2a, ethnicity in the sample is plotted alongside national statistics for ethnic demographic distribution for the top responding countries. In each country the sample was less diverse than the national context. The USA is the most diverse of the four, had the largest number of responses, and showed the most severe underrepresentation in the Hispanic and black/African categories. For these comparisons, note that we cannot formally distinguish between lack of diversity in the permaculture movement and bias in our sample. The degree of difference, however, makes it highly plausible that diversity is a real issue in the permaculture network. 
Table 1. Demographic distribution among 731 permaculture survey respondents. The left-most column shows distribution in the total sample. The other two blocks of columns show responses from the four top-responding countries, and all other responses divided into three categories accorded to Human Development Index, respectively. (a) Gender responses are within 10\% of a 1:1 male:female sex ratio for the total sample and most subgroups. No respondents identify their gender as other in either the low or middle other/HDI grouping. Of the top 4 responding countries, the highest level of respondents identifying gender as other are UK and USA (0.03 and 0.02, respectively), and the lowest is Australia (0.01). (b) Ethnicity: Every subgroup shows a white supermajority. The most diverse responses come from each of the three subgroups outside of the 4 top-responding (and white majority) countries. Despite white demographic dominance across subgroups, the proportional ethnicity of the permaculture movement appears to shift with regional ethnic context. (c) Education: Of the top four responding countries, Australia had the highest percentage of respondents who had not completed any post-high school degree (27\%), followed by the UK (24\%), the USA (14\%), and Canada having the lowest percentage $(12 \%)$. (d) The overall sample ratio of homeowners to renters (ignoring family and other categories) is $1.7: 1$, suggesting intermediateto-high socioeconomic status. Among the four top-responding countries, Australia has the highest ownership:rental ratio at 2:1, and the UK the lowest at $0.73: 1$. (e) Relative income, or income as a proportion of the national median income: Missing values are created both by nonresponse and by lack of data on national median income, and thus all 15 potential responses in the lowest other/HDI category are missing. The median for the total and for 4 of the 6 subgroups is below the national median. This contrast with the other socioeconomic status indicators (that suggest intermediate-to-high SES) highlights the ways in which income may not be a powerful indicator of socioeconomic status in this context, due to conscious lifestyle choices among participants that may restrict income but do not necessarily alter other aspects of SES.

\begin{tabular}{|c|c|c|c|c|c|c|c|c|}
\hline & \multirow[t]{2}{*}{ Total } & \multirow[t]{2}{*}{ USA } & \multirow[t]{2}{*}{ Australia } & \multirow[t]{2}{*}{ Canada } & \multirow[t]{2}{*}{ UK } & \multicolumn{3}{|c|}{41 other countries by HDI } \\
\hline & & & & & & $0.42-0.63$ & $0.69-0.84$ & $0.87-0.98$ \\
\hline Responses & 731 & 433 & 112 & 60 & 38 & 15 & 30 & 43 \\
\hline $\begin{array}{l}\text { Number of } \\
\text { countries }\end{array}$ & 45 & 1 & 1 & 1 & 1 & 8 & 17 & 16 \\
\hline & \multicolumn{8}{|c|}{ Gender } \\
\hline Female & 389 & 230 & 66 & 28 & 29 & 8 & 14 & 14 \\
\hline Male & 328 & 193 & 45 & 31 & 8 & 7 & 16 & 28 \\
\hline Other & 14 & 10 & 1 & 1 & 1 & 0 & 0 & 1 \\
\hline $\begin{array}{l}\text { White/ } \\
\text { Caucasian }\end{array}$ & 661 & 391 & 106 & 56 & y 34 & 12 & 23 & 39 \\
\hline Hispanic & 16 & 7 & 1 & 0 & 0 & 1 & 4 & 3 \\
\hline $\begin{array}{l}\text { Asian or Pacific } \\
\text { Islander }\end{array}$ & 10 & 3 & 2 & 2 & 0 & 1 & 2 & 0 \\
\hline $\begin{array}{l}\text { Black/African } \\
\text { American }\end{array}$ & 9 & 8 & 0 & 1 & 0 & 0 & 0 & 0 \\
\hline Native & 6 & 5 & 0 & 1 & 0 & 0 & 0 & 0 \\
\hline NA & 29 & 19 & 3 & 0 & 4 & 1 & 1 & 1 \\
\hline & \multicolumn{8}{|c|}{ Education } \\
\hline High School & 125 & 60 & 30 & 7 & 9 & 4 & 8 & 7 \\
\hline 2 Year College & 114 & 60 & 21 & 15 & 4 & 4 & 6 & 4 \\
\hline 4 Year College & 300 & 193 & 43 & 24 & 13 & 6 & 6 & 15 \\
\hline Masters & 158 & 99 & 17 & 12 & 9 & 1 & 8 & 12 \\
\hline $\mathrm{PhD}$ & 34 & 21 & 1 & 2 & 3 & 0 & 2 & 5 \\
\hline & \multicolumn{8}{|c|}{ Residence } \\
\hline Own & 344 & 208 & 62 & 32 & 11 & 5 & 12 & 14 \\
\hline Rent & 200 & 114 & 31 & 17 & 15 & 2 & 3 & 18 \\
\hline Family & 69 & 36 & 8 & 5 & 4 & 3 & 7 & 6 \\
\hline Other & 75 & 44 & 9 & 5 & 7 & 1 & 5 & 4 \\
\hline NA & 43 & 31 & 2 & 1 & 1 & 4 & 3 & 1 \\
\hline & \multicolumn{8}{|c|}{ Relative Income } \\
\hline $\operatorname{Max}$ & 22.5 & 22.5 & 11.79 & 5.26 & 3.13 & NA & 15.3 & 7.19 \\
\hline Median & 8 & 0.77 & 1.010 & 0.885 & 0.555 & NA & 2.025 & 0.85 \\
\hline Min & 0.00 & 0.02 & 0.03 & 0.03 & 0.06 & NA & 0.08 & 0 \\
\hline NA & 147 & 70 & 10 & 6 & 10 & 15 & 20 & 16 \\
\hline
\end{tabular}


Fig. 2. (a) Permaculture lacks ethnic diversity. The figure shows a comparative plot of proportional ethnicity, contrasting sample with national distribution for each of the four top-responding countries. In addition to nonresponses, grey blocks here include ethnic categories in national data that do not match with survey categories. In each country the sample is less diverse than the national context. The most diverse of the four countries, the USA, also has the largest number of responses, showing conspicuous underrepresentation in the Hispanic and black/ African categories. (b) Permaculturists have received more schooling than average. The figure shows a comparative plot of level of education, contrasting sample with national distribution for each of the four top-responding countries. Transparent bars connect corresponding levels to aid interpretation. The sample lacks any responses in the lowest level of pre-high school education. Overall, the darker colors in the sample columns show higher levels of education than the national distribution for each country.
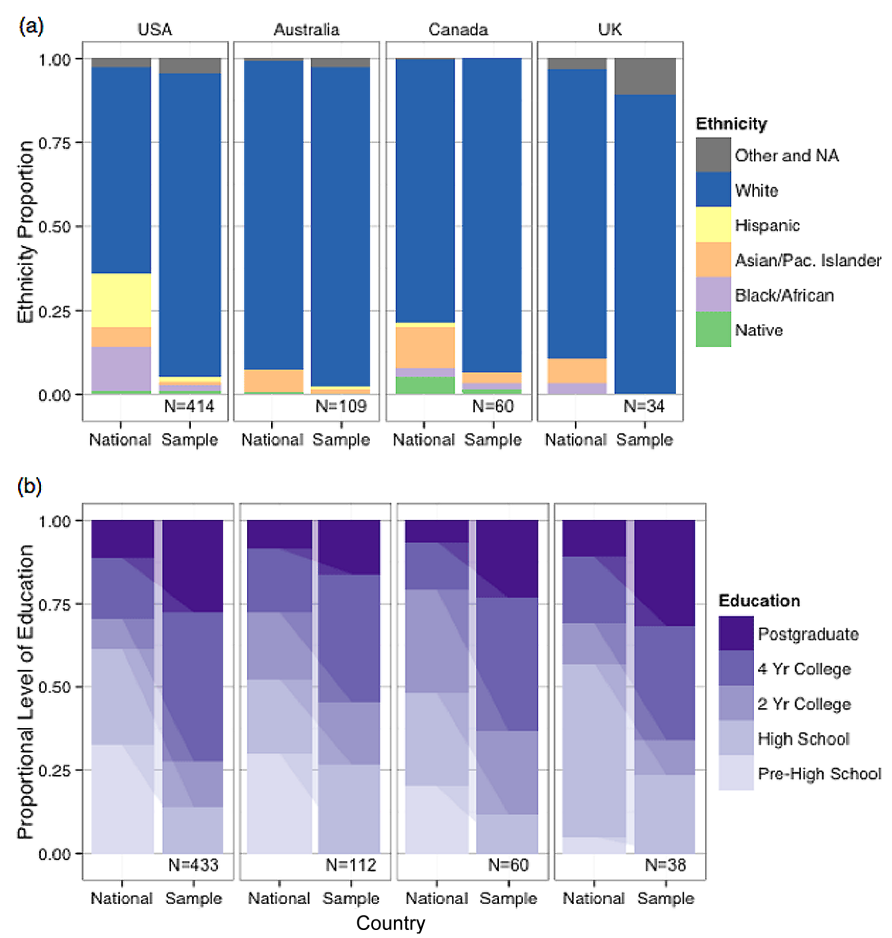

Socioeconomic status indicators

Indicators of socioeconomic status (SES) included level of education, status of current residence (own/rent/family/other), relative income (annual income as proportion of the national median). For education, the most numerous responses overall, in descending order, were 4 Year College (300), Masters (158), High School (125), 2 Year College (114), PhD (34), and Primary School (1 - not displayed in plots). Of the top four responding countries, Australia had the highest percentage of respondents who had not completed any post-high school degree $(27 \%)$, followed by the UK
(24\%), the USA (14\%), and Canada having the lowest percentage $(12 \%)$. Across all other countries, $26 \%$ of respondents had not completed any post-high school degree. Education level in the sample is plotted alongside national education statistics for the top four responding countries (Figure 2b). As above, note we cannot formally account for bias in our sample in making this comparison.

In the overall sample, 433 respondents indicated that they own their current residence, 200 rent, 69 live with family, 75 in some other arrangement, and 43 nonresponses. The USA respondents reported the highest percentage of ownership $(60 \%)$ and the UK the lowest $(29 \%)$. The overall ratio of homeowners to renters (ignoring the other categories) was 1.7:1, suggesting intermediate to high socioeconomic status.

For relative income, missing data were generated both by nonresponse (accounting for the majority of missing entries) and by the lack of national income data for a small number of countries, leaving 584 responses for analysis (USA $\mathrm{N}=363$, Australia $\mathrm{N}=102$, Canada $\mathrm{N}=54, \mathrm{UK} \mathrm{N}=28$, all others $\mathrm{N}=$ 37). The sample-wide median value for relative income was 0.8 .

\section{Response variables}

The most commonly identified role was community member (501 responses), followed by student (489), practitioner (488), designer (309), activist (306), teacher (283), organizer (281), consultant (235), and professional (159). Respondents were asked to check all applicable roles. The median number of roles selected was four.

\section{Factor analysis}

Parallel analysis and optimal coordinates analysis both indicated the retention of three factors (Raîche et al. 2013). Factor adequacy was confirmed with the Kaiser-Meyer-Olkin Measure of Factor Adequacy, using the KMO function in the R psych package (Kaiser 1974, Revelle 2012). The Overall Measure of Sampling Adequacy was 0.88 ("great," cf. Kaiser 1974). The largest item sampling adequacy score was for the role of activist (0.92, 'superb', ibid.) and the smallest was student (0.76; "good," Kaiser 1974). The first factor was labeled "professional" (Kaiser 1974) and included the variables for consultant (1), designer (0.9), professional (0.7), and teacher (0.5; Fig. 3). The second factor was labeled "relational" and its loadings included organizer (0.9), community member (0.7), and activist (0.7). The third and final factor was labeled "practice" and its loadings were practitioner $(0.7)$ and student $(-0.4)$. Note the single negative loading of student on the practice factor: identifying as a student lowers respondents' score on this dimension, and vice versa.

\section{Fitted model}

Model results are displayed as a coefficient plot (Fig. 4). Posterior means are plotted as points, and are analogous in practice to estimated coefficients in a frequentist framework. Error bars represent 95\% Highest Posterior Density, and are analogous in practice to $95 \%$ frequentist confidence intervals (Hadfield 2010). In keeping with the exploratory nature of this study, for the purposes of discussion we relax the credibility threshold to $90 \%$, and additionally that displayed an effect size commensurate with other credible predictors (Kirk 1996, Coe 2002, Maher et al. 2013). 
Fig. 3. Factor structure of nine role variables to three dimensions. This figure shows the loading of the original "check all that apply" role variables onto three factors, with the color and transparency of original variables showing grouping and strength of association. Factor structure shows distinct dimensions of participation, delineating between social and biophysical roles, and between higher and lower status roles. Within social roles, high-status, professional, public-interface roles, loading on the factor labelled "professional," and lower status, relational, and likely unpaid roles loading on the factor labelled "relational." Biophysical participation is captured in the third factor, labeled "practice," which is loaded only by the roles of practitioner and student. Note that the loading of student is negative, so checking off the student role lowers a respondents score on the practice factor, and vice versa.

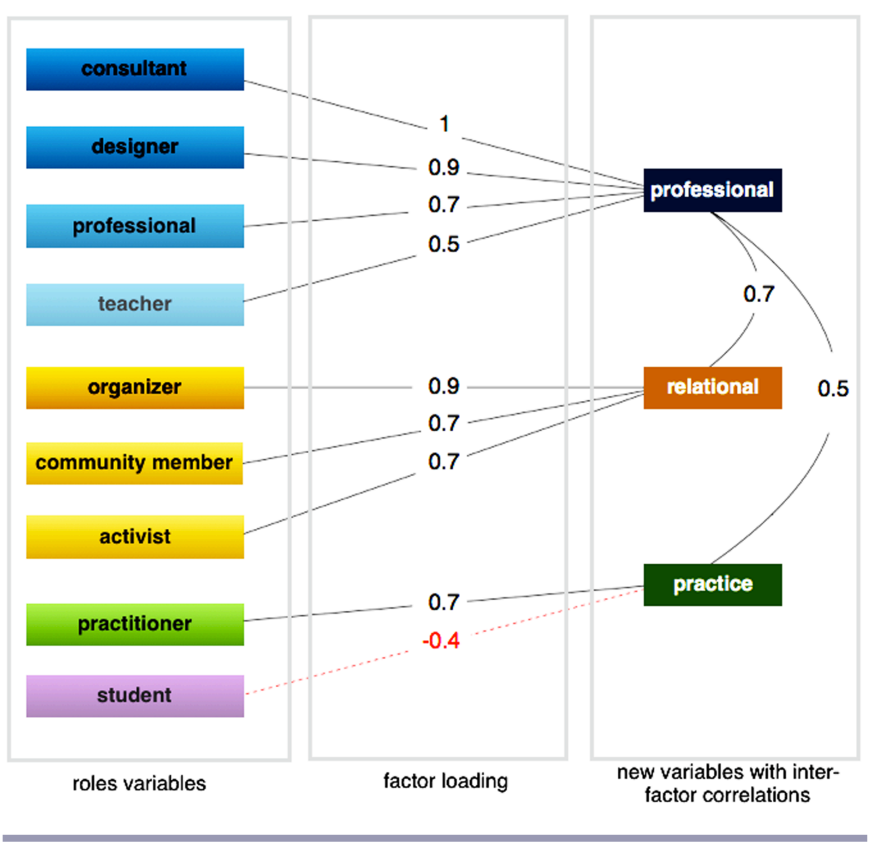

\section{Personal variables}

Age and gender both had significant positive effects on the practice dimension. The strongest effect among the personal variables was the positive effect of male gender on the professional dimension. None of the effects of race were significant, but the size of its negative effect on the relational dimension was commensurate with other significant effects.

\section{Socioeconomic status indicators}

The effects of SES indicators were highly varied. Income had no significant effects. Homeownership negatively impacted professional and relational dimensions, and had a positive effect on the practice dimension. Education had a positive effect on all three response variables. The strongest observed effect was that of two years of college (contrasted with high school) on practice. The strongest effect among all SES indicators was the negative effect of homeownership on the relational dimension.

\section{Structural variables and national language}

The strongest effects among the national-level variables were from national language, with residence in a nonanglophone country having a negative effect on the relational dimension, and a strong positive effect on the practice dimension. Inequality had a significant positive effect on the practice dimension. Ecosystem vitality had a significant negative effect on the professional dimension.

Fig. 4. Model results show effects of socio-demographic and structural factors on dimensions of participation. The position of points for each predictor across three $\mathrm{x}$-axes shows the mean of the posterior distribution, analogous in practice to estimated coefficients in a frequentist framework. The zero line indicates no effect of the predictor. Error bars represent 95\% Highest Posterior Density, and are analogous in practice to $95 \%$ confidence intervals in a frequentist framework. Points and error bars are colored to show effect size, as the absolute value of the coefficient. Predictors not significant at $90 \%$ credibility are shown at $50 \%$ transparency. SES indicates socioeconomic status.
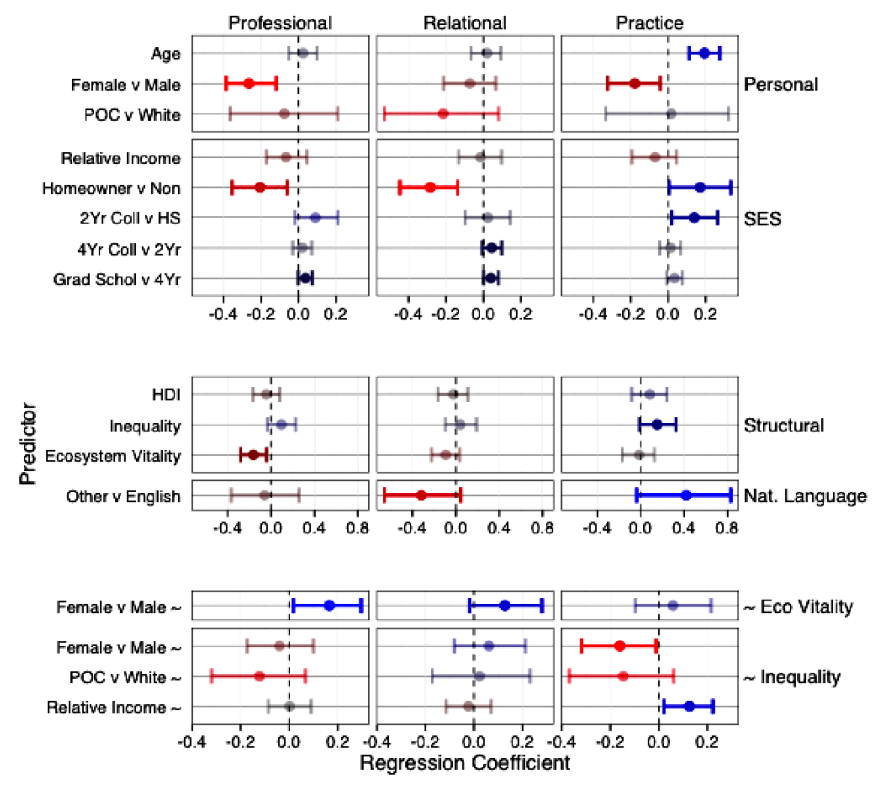

Cross-scale interactions

The model displayed several significant interactions between national- and individual-level predictors. Gender displayed significant interactions with the structural variables of inequality and ecosystem vitality (Fig. 5). For both professional and relational dimensions, the relationship between men's and women's scores inverted across the gradient of ecosystem vitality, with men's scores negatively correlated with ecosystem vitality. Gender also interacted with national-level inequality to affect the practice dimension, such that as inequality increases, the practice gender gap increases.

Inequality also had a significant interaction with relative income, and sizable observed interactions with race, affecting the practice dimension. As inequality increases, relative income shifts from a slight downward slope to a strong upward slope (Fig. 6). In other words, at high levels of inequality, practice increases with relative income. The strength and direction of the observed interaction between inequality and race suggests that as inequality increases, POC identity has an increasingly negative influence on both professional and practice dimensions. 
Fig. 5. Women's participation in professional and relational dimensions is only slightly affected by ecosystem vitality, while men's participation on these dimensions declines as ecosystem vitality increased. Dimensions of participation are plotted on the $\mathrm{y}$-axis and conditioning variables on the $\mathrm{x}$-axis. Plots show model predictions (with unplotted variables held at constant values) and 95\% Highest Posterior Density bands. Rug plots along each axis show the distribution of individual responses.

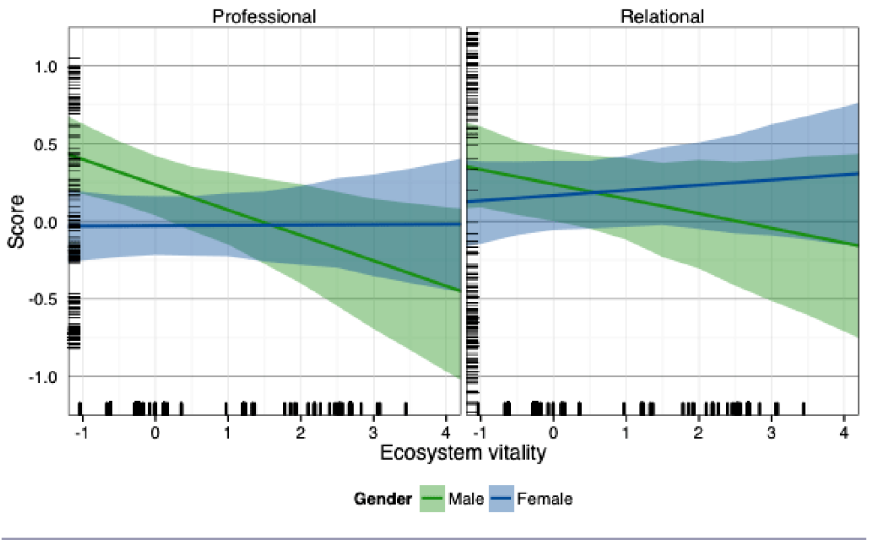

Fig. 6. Income drives participation in practice roles, and the strength and direction of the effect is determined by nationallevel inequality. Plot shows model predictions (with unplotted variables held at constant values) and 95\% Highest Posterior Density bands. Rug plots along each axis show the distribution of individual responses.

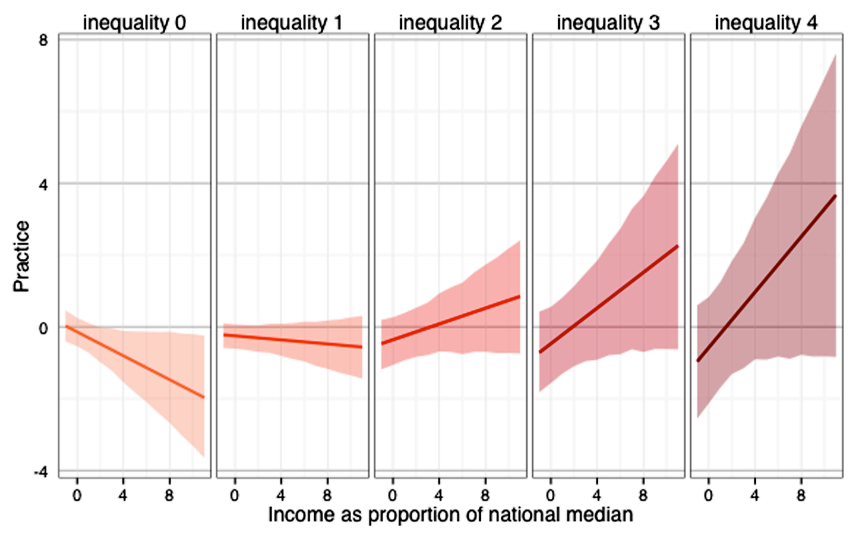

\section{DISCUSSION}

This project offers a first look at the socio-demographic characteristics of participation in the international grassroots network known as permaculture. Our approach focuses on variation within the movement, with a coarser look at the degree to which survey responses resemble national demographic distributions. Factor analysis and regression modeling illustrate the effects of gender, race, and SES on participation within the movement across multiple dimensions of participation. By including national-level indices in the model, our approach also offers an opportunity to further investigate the interactions between individual factors and larger scale forces in an international context. Our findings show that gender and class are interacting with dimensions of participation in complex ways that vary across international socio-environmental context. Our findings complicate both cultural and material explanations of environmental action, and highlight the importance of multiple dimensions of participation as well as the multiple levels and locations through which social forces shape grassroots participation.

\section{Socio-demographic overview}

Survey responses show high/representative levels of diversity in age and gender and very low levels of diversity in ethnicity. The good news of proportional gender participation is moderated by our findings of gendered differences in participation. The bad news of disproportionately low ethnic diversity is compounded by observed, though nonsignificant, effects that suggest racial disparities in participation. The size of racial effects in the model, compared to other significant effects such as gender, prompt us to take these effects seriously despite their lack of statistical significance (Coe 2002, Maher et al. 2013). The observed effects suggest that people of color are overall less likely than white/ Caucasian people to participate in relational roles, and that racial disparities in the professional and practice dimensions appear and grow as structural inequality increases. These constraints may be due to increasingly limited access to the resources required to participate (such as time), increasing feelings of powerlessness that accompany marginalization, or increasing cultural alienation between privileged and marginalized subcultures, or some combination of these factors. Determining which is beyond the scope of this project.

The socioeconomic make-up of the permaculture network remains somewhat ambiguous. Although relative income does not itself suggest disproportionately high SES, respondents do show higher than representative levels of education and intermediate to high levels of homeownership. For an environmentally focused counterculture, such as that associated with permaculture, income may not be as meaningful an indicator of socioeconomic status as other factors, owing to conscious lifestyle choices among participants that may restrict income but do not necessarily alter other aspects of SES (Halfacree 2001, Hamilton and Mail 2003).

\section{Modes of participation}

The clustering of the raw variables within the three extracted factors of professional, relational, and practice, illustrate multiple distinct dimensions of participation. The dimension we labeled professional is associated with high-status, public, and professional roles, while the dimension we labeled relational is associated with the work of generating and maintaining the network, roles that are less likely to be high-status, professional, or paid positions. The correlation of professional and relational, however, suggests that these dimensions are mutually compatible. We interpret the dimension we called practice to indicate engagement with some biophysical dimension, whether in the form of (for example) shifts in lifestyle, environmentally relevant behaviors around the household, horticultural or agricultural activities, or some other activity that is not purely social/ relational. The weaker and absent correlation of either relational 
or professional with practice, respectively, points toward a degree of the autonomy between social (professional, relational) and biophysical (practice) modes of engagement. Participation in the form of practice could either bolster the two social modes of participation or compete with them, depending on the context and circumstances of the practitioner. The fitted model reinforces this picture of autonomy between social and biophysical participation.

\section{Gender, environmental threat, and sexism}

Women are represented in the sample at or above their presence in the general population, but their participation in professional and practice roles, when compared to men, is not proportional to their presence in permaculture. The significant interaction with ecosystem vitality creates an interesting commentary on gendered differences in environmental participation. Women's socialization as caregivers has been hypothesized to heighten their vigilance against potential threats to the members of their household, and thus to care more about environmental issues (Mohai 1992). The intensity of women's involvement should therefore be highest at low levels of ecosystem vitality, especially in the dimension of practice, because they respond to visible and imminent environmental threats. But this is not the case, and rather it is men's responses that are higher in more ecological degraded environments.

On the other hand, the relative exclusion of women from access to economic resources has been offered as an explanation of lower levels of women's participation in public sphere. The theory of biographical availability supposes that women are less available than men to participate in environmental activity outside of the private sphere because of the demands of the household and reduced discretionary resources (Xiao and McCright 2014). This would lead us to expect that women's public involvement would be more constrained at higher levels of structural inequality, while potentially private roles such as practice would remain unaffected. Instead, we see the reverse: inequality does not appear to modulate the effect of gender on relational or professional dimensions, but amplifies the gender gap in the practice dimension.

These results confound the cultural and biographical explanations for gendered differences in participation. In the absence of support for these theories, the evidence points toward the more general explanation of ubiquitous gender bias, including both external and internalized sexism. Women receive less support and more criticism for taking on professional roles (Eagly et al. 1995, Eagly and Karau 2002), and the worth of their contributions is systematically underestimated by others (England 1992) and by themselves (Kray and Babcock 2006). These forces are likely driving both the roles that women actually perform in permaculture as well as how they identify their roles.

\section{Costs and yields of practice}

It is a foundational assumption that the practice of permaculture should be beneficial for individuals across a wide swath of SES, yielding a net material benefit to the practitioner without extensive capital investment. Participation as a practitioner, however, appears to be constrained by access to resources. At the individual level, the practice dimension is positively and significantly correlated with age, male gender, college education, and homeownership. These individual-level associations are reinforced by structural and cross-scale effects. Increasing inequality at the national level exacerbates gender disparity in the practice dimension. Higher practice scores are associated with respondents from nonanglophone countries, who are likely to have increased access to resources, either as highly educated native citizens of their countries of residence, or as immigrants or visitors from anglophone countries. Last, under high levels of structural inequality, practice becomes positively correlated with income, and has a stronger observed (though not significant) correlation with white/Caucasian racial identity.

Theories of barriers to participation appear to explain this aspect of our results well: practice is constrained by access to resources, and as the distribution of social and economic goods becomes increasingly unequal, the capacity of marginalized groups to practice permaculture is progressively curtailed (Parker and McDonough 1999). This is an unsurprising but nevertheless important finding for practitioners and advocates of grassroots transition networks such as permaculture. These are not, however, grounds to reject the notion of material benefits for practitioners. First, the effects described above may reflect initial barriers, i.e., start-up costs, rather than longer term potential benefits. Second, as noted above, those excluded from our sample, by lack of internet access and/or lack of facility with English, include important sectors of permaculture practitioners, especially smallholders and other subsistence producers in the developing world, for whom the limited evidence available suggests permaculture may offer concrete benefits (Terui 2000, Meigs 2004, Felix-Romero 2010, Conrad 2014). Third, we should exercise caution in our interpretation of the interaction between income and inequality because it is possible that in highly unequal countries, the practice of permaculture drives income rather than vice versa.

\section{Subjective values, objective buffers}

In light of theories of biographical availability, barriers to participation, and postmaterialist values, we might expect that increasing indicators of socioeconomic status and human development would drive increasing intensity of involvement along professional and relational roles as well, i.e., more affluence equals more participation (Parker and McDonough 1999, Dunlap and York 2008, Xiao and McCright 2014). The variation in the effects of relative income, homeownership, and education, across dimensions of participation and structural factors, supports a framework that distinguishes between cultural and material components of SES on one hand and dimensions of engagement on the other. It would appear that some types of affluence promote engagement with environmental issues, whereas others act as a buffer between affluent communities and the socialecological consequences of affluence, and its attendant consumption.

\section{Implications}

For both scholars of permaculture and participants, this study is intended to ameliorate the tendency to regard permaculture as unique phenomenon, a movement sui generis. Although permaculture possesses its own distinctive characteristics, it is in many ways much like other environmental movements of the industrialized world, especially in that its participants are largely white/Caucasian and of intermediate to high SES. Like other environmental movements, the factors limiting diversity and equality in permaculture must be addressed thoughtfully and 
Fig. 7. Boundary and terrain: a multilevel, multiloci model of the influence of socio-demographic and structural factors on participation in movements and networks. Movement and network characteristics interact with sociodemographic factors to shape participant demography at two thresholds or loci: (1) simple encounter of the movement/network by the potential participant, and entry of the participant into the movement/network, and (2) a multidimensional participation profile. Participation is also affected by socio-environmental context, both directly and indirectly, as structural factors act directly on participation while also modulating the effects of participant demography.

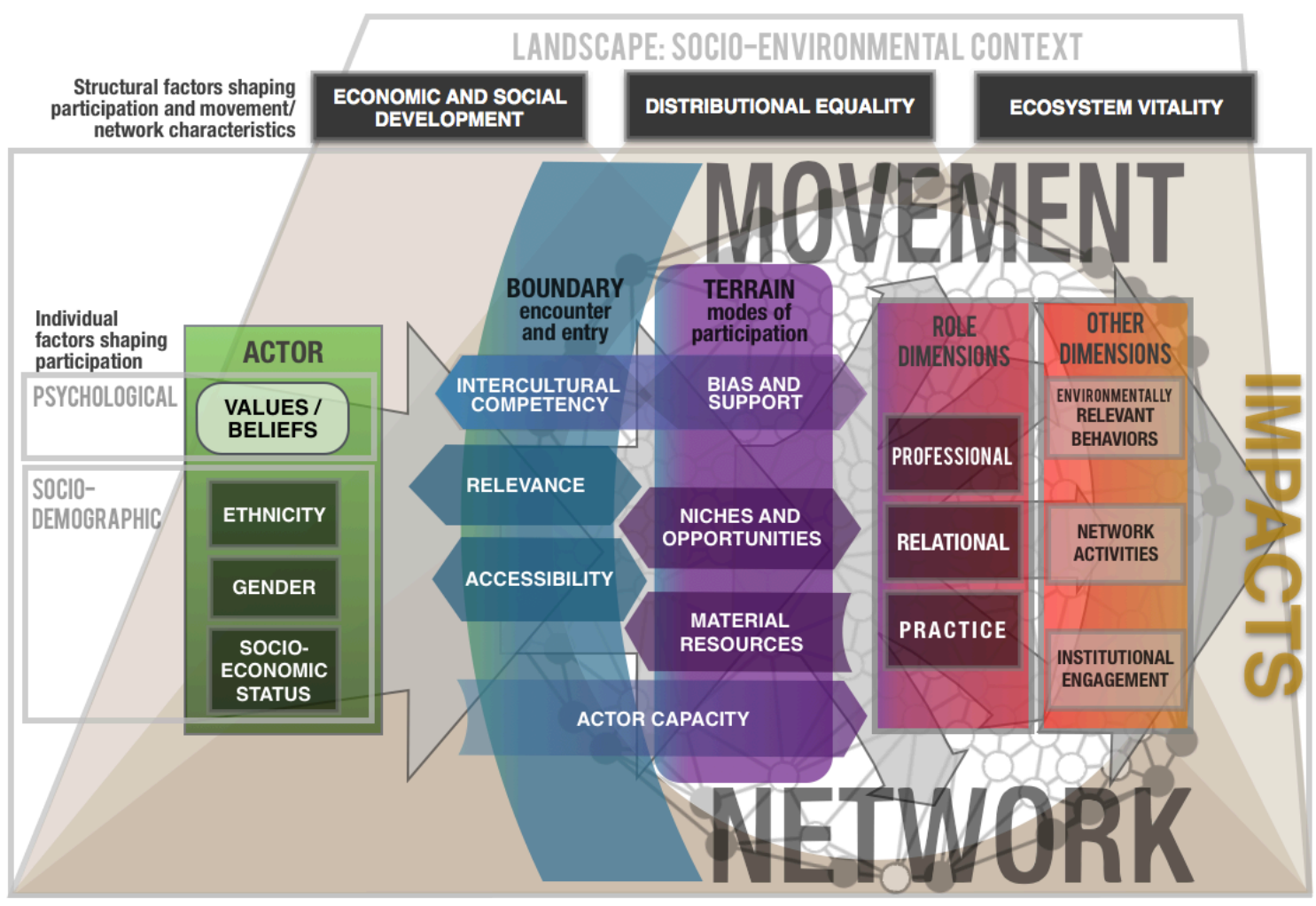

systematically if permaculture is to make a meaningful contribution to societal transition to sustainability. Researchers addressing permaculture should consider the ways in which permaculture can fit into existing theoretical frameworks of movement and networks as well as the ways in which it does not sit easily into any (Ferguson and Lovell 2012). The literatures of environmental movements and innovation networks are both useful resources for identifying key questions.

For scholars of grassroots innovation networks, this study demonstrates the need for attention to questions of access, diversity, and the socio-demographic constraints that shape them. The focus on informal networks of innovation, rather than traditional forms of mobilization around political and environmental campaigns, cannot be a reason to elide the political dimensions of grassroots sustainability efforts. For social movement scholars who are already steeped in analysis of drivers of participation, this study offers both a call to continue expanding investigation of the dimensions of participation into classical environmental movements and novel network-based forms of organization.

The parallels and contrast between the effects of gender, race, and SES, point the way toward a perspective that takes into account the multiple levels and loci at which socio-demographic and structural factors shape the capacity of grassroots actors to participate in innovation networks and environmental movements. It is clear that related but distinct constraints act differentially on (1) entry, or simple encounter and engagement with the movement and (2) the kind and intensity of involvement once engaged. For example, the comparisons between sample and national demography show that whatever factors exclude POC do not also exclude women. Once engaged with the movement, however, being a woman depresses the professional dimension more than being a person of color, though both are affected negatively. It is possible that for those POC who become involved with a white/Caucasian-dominated movement such as permaculture, the barriers to entry act as a filter that selects for personal qualities and capacities that mitigate, but do not eliminate, barriers to involvement in high-status roles.

The diagram in Figure 7 illustrates a theoretical framework of boundary and terrain that attempts to integrate the forces that shape participation operating at multiple levels and loci. We do not intend that this framework fully address grassroots participation in all its psychological and social complexity (Kitts 2000, Bamberg and Möser 2007), but rather illuminate the role 
of socio-demographic and structural factors and their most explicit cultural aspects. We continue to use the term network in this discussion, but intend that this model should apply equally to movements.

It should be uncontroversial to observe that, in general, the interaction between an individual actor and a grassroots network is shaped by the resources and position of the actor, including psychological and material factors, and the distribution, cultural characteristics, and material resources of the network. Our model of participation proposes four main elements: actor, boundary, terrain, and landscape. The set of individual actor characteristics we identify is intended to be fairly standard, in relation to the literature of social movement studies. We use the term boundary to refer to processes that shape encounter and basic involvement with the network. For any given actor and their capacity, the possibility of encountering and entering a network is determined by the relationship between their own interests and capacities, and that of the network: accessibility (location, timing, and publicity of meetings), personal relevance, and cultural competency (the degree to which information about the network is conveyed in a way that is welcoming and inoffensive). Boundary processes at the grassroots have received considerable scholarly attention in multiple disciplines (Newell et al. 2000, Pachucki et al. 2007), including in the limited body of scholarly research on permaculture (Ingram et al. 2014).

Once an actor encounters and becomes involved with the network, i.e., passes or is admitted by boundary processes, an overlapping but distinct set of forces operates to shape the actor's participation. We refer to these processes as the terrain. The dimensions and scope of participation are determined by their interaction between actor characteristics, and the interplay of cultural attitudes (such as bias and support), material resources and their disposition, and other characteristics of the network. We refer to the larger socio-environmental context as the landscape, in which structural factors directly and indirectly influence participation, both shaping the prospects of the network as a whole and modulating the effects of individual sociodemographic factors. The factors shaping participation must be regarded as multilevel and multiloci because participation itself is multidimensional and multilocal: from personal to public, from social to biophysical, and from relational to instrumental.

\section{Limitations of this study}

This study is based on a convenience sample, so exact inference about the population of permaculture participants is not possible. The survey sample is likely skewed in both predictable and unpredictable ways by several factors: as a nonrandom sample, by English-only survey availability, and by web-only administration. As noted above, this survey entirely excludes important sectors of the permaculture movement that lack web access and/or facility with English. Within industrialized countries, the web-only format would predictably cause a skew toward high SES, and within nonanglophone countries in the developing world, the English language format and web-only format would likely produce an even more pronounced bias. We should not assume that diversity and participation in permaculture in the developing world, in non-English speaking populations, and in lower SES groups, are well demonstrated by this study. This study also relies solely on self-report of roles as a single (if multidimensional) index of engagement. Other metrics to quantify engagement may be more informative.

\section{Future directions}

This study suggests several avenues for future research. The questions driving this study should be extended to encompass other dimensions of participation beyond role identification, including environmentally relevant behaviors and involvement in network activities, e.g., hosting and attending events, giving and receiving aid, etc. To understand permaculture's actual and potential contributions to transitions to sustainability, we must assess exogenous, outward-facing outcomes as well. How does permaculture influence participant's public and/or professional lives? How, if at all, do participants integrate the permaculture worldview and principles into their relationship with institutions, their activism, or their life in civil society? Each of these questions can be addressed in an exploratory fashion with the remainder of the dataset used for this study, though interpretation will necessarily be constrained by the same limitations of the sample discussed above. Studies based on this dataset should inform further research making use of random and/or stratified sampling, multiple language availability, and multiple format administration, that can eliminate sampling bias and create a basis for strong statistical inference about the population of the permaculture movement.

Another key avenue is highlighted by those respondents who are participating in modes that are unusual for their sociodemographic group, and points to questions best addressed through qualitative research: What is the experience of women in professional and practice roles in permaculture, and what are the forces that facilitate their participation? What is the experience of the small number of people of color who do participate, and what facilitates their participation? How can the permaculture movement, and grassroots networks and movements generally, support diverse and representative participation?

\section{CONCLUSION}

With the slow pace of institutional change in response to global environmental crises, further attention to the capacity of grassroots actors to foster transitions to sustainability is needed. This article is intended to address both scholars of grassroots sustainability transitions and participants, particularly in the permaculture movement. To transition scholars, we have made the argument that the cross-scale interaction between sociodemographic and structural factors points the way toward a perspective that stresses the multiple levels and loci at which these forces exert themselves, and thereby shape and constrain the participation of grassroots actors. Any such perspective must take into account the multidimensionality of participation, and seek to avoid the simple dichotomies that threaten to obscure the richness and variety with which people engage with the task of transitioning to sustainability.

In addressing scholars of permaculture and the permaculture movement itself, we have shown that despite its distinct strengths, permaculture faces many of the same struggles around inclusion and diversity as other environmental movements with their origins in the global North. Expanded racial and economic diversity in movement participation overall, and expanded gender diversity in professional and practice roles, are critical for 
permaculture to contribute substantively to a transition to sustainability. Despite a lack of formal hierarchy, the network structure of permaculture demonstrably fails to create an inclusive and diverse movement. Permaculture participants and advocates should consider strategies to build institutional capacity in ways that enable systematic efforts to expand meaningful diversity while maintaining safeguards against cooptation.

Some permaculturists are taking up this challenge, as evidenced in the USA by recent discussion of gender bias in permaculture and strategies for correcting it (Olson-Ramanujan 2013), the emergence of regional women-only permaculture gatherings, and the formation of the Black Permaculture Network, a POC-led organization with a mission of soliciting and directing funding to provide scholarships to support students of color in attending permaculture courses (http://blackpermaculturenetwork.org/). Although these developments are encouraging, there is much more to be done. The permaculture movement and its advocates face a complex dilemma in negotiating between two conflicting imperatives: that of conserving the model of change that has accompanied their international spread and successes to date, and changing that model in the face of the constraints it imposes on participation. This dilemma is not, of course, unique to permaculture, but it is critical. Currently, the lack of equitable diversity across participant roles casts a long shadow over the relevance of permaculture in the global context. If participants can successfully address the dilemma of grassroots diversity, then as a set of ideas and practices, and as an international movement, permaculture will have much to offer the formidable task of transitioning to sustainability.

Responses to this article can be read online at: http://www.ecologyandsociety.org/issues/responses. $\mathrm{php} / 8048$

\section{Acknowledgments:}

This manuscript benefited greatly from the thoughtful comments of several readers, including Catherine Bukowski, Frances Ming Kuo, and Emily Kawano, and especially the multiple reviews of Eleanor Andrews and Abigail Conrad. Many thanks to all the permaculturists who took the time to respond to the survey, and additional thanks to those who also helped promote it.

\section{LITERATURE CITED}

Adams, J. H. 1992. The mainstream environmental movement. EPA Journal 18:25.

Alkire, S., and J. Foster. 2010. Designing the inequality-adjusted human development index (HDI). Oxford Poverty \& Human Development Initiative, Oxford, UK.

Allen, P., and J. Guthman. 2006. From "old school" to "farm-toschool": neoliberalization from the ground up. Agriculture and Human Values 23:401-415. http://dx.doi.org/10.1007/s10460-006-9019$\underline{z}$
Anderson, D. R. 2008. Model based inference in the life sciences: a primer on evidence. Springer, New York, New York, USA. http:// dx.doi.org/10.1007/978-0-387-74075-1

Assadourian, E., T. Prugh, and L. Starke. 2013. State of the world 2013: Is sustainability still possible? Island Press, Washington, D. C., USA.

Bamberg, S., and G. Möser. 2007. Twenty years after Hines, Hungerford, and Tomera: a new meta-analysis of psycho-social determinants of pro-environmental behaviour. Journal of Environmental Psychology 27(1):14-25. http://dx.doi.org/10.1016/ j.jenvp.2006.12.002

Beddoe, R., R. Costanza, J. Farley, E. Garza, J. Kent, I. Kubiszewski, L. Martinez, T. McCowen, K. Murphy, N. Myers, Z. Ogden, K. Stapleton, and J. Woodward. 2009. Overcoming systemic roadblocks to sustainability: the evolutionary redesign of worldviews, institutions, and technologies. Proceedings of the National Academy of Sciences 106(8):2483-2489. http://dx.doi. org/10.1073/pnas.0812570106

Bell, S. E., and Y. A. Braun. 2010. Coal, identity, and the gendering of environmental justice activism in Central Appalachia. Gender \& Society 24(6):794-813. http://dx.doi.org/10.1177/0891243210387277

Bergman, N., N. Markusson, P. Connor, L. Middlemiss, and M. Ricci. 2010. Bottom-up, social innovation for addressing climate change. Environmental Change Institute Working Paper. Environmental Change Institute, Oxford, UK. [online] URL: http://eprints.uwe.ac.uk/13788

Berkes, F., J. Colding, and C. Folke. 2003. Navigating socialecological systems: building resilience for complexity and change. Cambridge University Press, Cambridge, UK. http://dx.doi. org/10.1017/cbo9780511541957

Bethlehem, J., and S. Biffignandi. 2011. Handbook of web surveys. John Wiley \& Sons, Hoboken, New Jersey, USA. http://dx.doi. org/10.1002/9781118121757

Blann, K., S. Light, and J. A. Musumeci. 2003. Facing the adaptive challenge: practitioners' insights from negotiating resource crises in Minnesota. Pages 210-240 in F. Berkes, J. Colding, and C. Folke, editors. Navigating the dynamics of social-ecological systems: building resilience for complexity and change. Cambridge University Press, Cambridge, UK. http://dx.doi.org/10.1017/ cbo9780511541957.014

Bonilla-Silva, E. 2009. Racism without racists: color-blind racism and the persistence of racial inequality in America. Third edition. Rowman \& Littlefield, Lanham, Maryland, USA.

Brechin, S. 1999. Objective problems, subjective values, and global environmentalism: evaluating the postmaterialist argument and challenging a new explanation. Social Science Quarterly 80:793-809.

Burleson, P. E. 2010. Collaborative community-based natural resource management. Fordham Environmental Law Review 21 (201).

Burton, P. 2013. Rooted: overcoming complacency in planning for greater food security in Australian cities. State of Australian Cities National Conference. State of Australian Cities Research Network, Sydney, NSW, Australia. 
Clarke, K. A. 2011. Quantitative methods, basic assumptions. Pages 2176-2189 in B. Badie, D. Berg-Schlosser, and L. Morlino, editors. International encyclopedia of political science. Sage, Thousand Oaks, California, USA. http://dx.doi. org/10.4135/9781412959636.n498

Coe, R. 2002. It's the effect size, stupid: what effect size is and why it is important. Paper presented at the Annual Conference of the British Educational Research Association. University of Leeds, Leeds, UK. [online] URL: http://www.leeds.ac.uk/educol/ documents/00002182.htm

Coffé, H., and C. Bolzendahl. 2010. Same game, different rules? Gender differences in political participation. Sex Roles 62 (5):318-333. http://dx.doi.org/10.1007/s11199-009-9729-y

Conant, J. 2012. Planning for climate disaster: resilient communities respond. Race, Poverty \& the Environment 19 (2):31-33.

Congdon, P. 2014. Applied bayesian modelling. John Wiley \& Sons, West Sussex, UK. http://dx.doi.org/10.1002/9781118895047

Conrad, A. 2014. We are farmers: agriculture, food security, and adaptive capacity among the permaculture and conventional farmers in central Malawi. Dissertation, American University, Washington, D.C., USA.

Cornils, I. 2014. The struggle continues: Rudi Dutschke's long march. Student protest: the Sixties and after. First edition. Routledge, London, UK.

Culley, M. R., and H. L. Angelique. 2003. Women's gendered experiences as long-term Three Mile Island activists. Gender \& Society 17(3):445-461. http://dx.doi.org/10.1177/0891243203017003009

Davidson, D. J., and W. R. Freudenburg. 1996. Gender and environmental risk concerns: a review and analysis of available research. Environment and Behavior 28(3):302-339. http://dx.doi. org/10.1177/0013916596283003

Dawborn, K., and C. Smith. 2011. Permaculture pioneers : stories from the new frontier. Holmgren Design Services, Hepburn, Victoria, Australia.

Dellapenna, J. W., J. Gupta, W. Li, and F. Schmidt. 2013. Thinking about the future of global water governance. Ecology and Society 18(3):28. http://dx.doi.org/10.5751/es-05657-180328

Dietz, T., P. C. Stern, and G. A. Guagnano. 1998. Social structural and social psychological bases of environmental concern. Environment and Behavior 30(4):450-471. http://dx.doi. org/10.1177/001391659803000402

Dunlap, R. E., and R. York. 2008. The globalization of environmental concern and the limits of the postmaterialist values explanation: evidence from four multinational surveys. Sociological Quarterly 49(3):529-563. http://dx.doi.org/10.1111/ j.1533-8525.2008.00127.x

Eagly, A. H., and S. J. Karau. 2002. Role congruity theory of prejudice toward female leaders. Psychological Review 109 (3):573-598. http://dx.doi.org/10.1037/0033-295x.109.3.573

Eagly, A. H., S. J. Karau, and M. G. Makhijani. 1995. Gender and the effectiveness of leaders: a meta-analysis. Psychological Bulletin 117(1):125-145. http://dx.doi.org/10.1037/0033-2909.117.1.125
Einwohner, R. L., J. A. Hollander, and T. Olson. 2000. Engendering social movements: cultural images and movement dynamics. Gender \& Society 14(5):679-699. http://dx.doi. org/10.1177/089124300014005006

Emerson, J., D. C. Esty, M. A. Levy, C. H. Kim, V. Mara, A. de Sherbinin, and T. Srebotnjak. 2010. Environmental performance index. Yale Center for Environmental Law and Policy, New Haven, Connecticut, USA.

England, P. 1992. Comparable worth: theories and evidence. Transaction, New Brunswick, New Jersey, USA.

Ernstson, H., S. Sörlin, and T. Elmqvist. 2008. Social movements and ecosystem services - the role of social network structure in protecting and managing urban green areas in Stockholm. Ecology and Society 13(2):39. [online] URL: http://www. ecologyandsociety.org/vol13/iss2/art39/

Felix-Romero, J. 2010. Harvesting peace: permaculture as peacebuilding. George Mason University, Fairfax, Virginia, USA.

Feola, G., and R. Nunes. 2014. Success and failure of grassroots innovations for addressing climate change: the case of the transition movement. Global Environmental Change 24:232-250. http://dx.doi.org/10.1016/j.gloenvcha.2013.11.011

Ferguson, R. S., and S. T. Lovell. 2012. Hybrid ecological knowledge: permaculture and the political ecology of landscape regeneration. University of Kentucky, Lexington, Kentucky, USA.

Ferguson, R. S., and S. T. Lovell. 2014. Permaculture for agroecology: design, movement, practice, and worldview. A review. Agronomy for Sustainable Development 34(2):251-274. http://dx.doi.org/10.1007/s13593-013-0181-6

Folke, C., J. Colding, and F. Berkes. 2003. Synthesis: building resilience and adaptive capacity in social-ecological systems. Pages 352-387 in F. Berkes, J. Colding, and C. Folke, editors. Navigating social-ecological systems: building resilience for complexity and change. Cambridge University Press, Cambridge, UK. http://dx.doi.org/10.1017/cbo9780511541957.020

Fox, J. 2009. Polycor: polychoric and polyserial correlations. R package version 0.7-7. The Comprehensive R Archive Network, Vienna, Austria.

Freeman, J. 2013. The tyranny of structurelessness. WSQ: Women's Studies Quarterly 41(3\&4):231-246. http://dx.doi. org/10.1353/wsq.2013.0072

Fressoli, M., E. Arond, D. Abrol, A. Smith, A. Ely, and R. Dias. 2014. When grassroots innovation movements encounter mainstream institutions: implications for models of inclusive innovation. Innovation and Development 4(2):277-292. http://dx. doi.org/10.1080/2157930x.2014.921354

Fung, A., and E. O. Wright. 2001. Deepening democracy: innovations in empowered participatory governance. Politics and Society 29(1):5-41. http://dx.doi.org/10.1177/0032329201029001002

Gelissen, J. 2007. Explaining popular support for environmental protection: a multilevel analysis of 50 Nations. Environment and Behavior 39(3):392-415. http://dx.doi.org/10.1177/0013916506292014 
Gelman, A., J. B. Carlin, H. S. Stern, and D. B. Rubin. 2004. Bayesian data analysis. Texts in statistical science series. Chapman \& Hall/CRC, Boca Raton, Florida, USA.

Gerlach, L. P. 2001. The structure of social movements: environmental activism and its opponents. Pages 289-310 in Networks and netwars: the future of terror, crime, and militancy. RAND Corporation, Santa Monica, California, USA.

Grantham, J. 2012. Be persuasive. Be brave. Be arrested (if necessary). Nature 491(7424):303-303. http://dx.doi.org/10.1038/491303a

Guitart, D. A., J. A. Byrne, and C. M. Pickering. 2015. Greener growing: assessing the influence of gardening practices on the ecological viability of community gardens in South East Queensland, Australia. Journal of Environmental Planning and Management 58(2):189-212. http://dx.doi.org/10.1080/09640568.2013 .850404

Gunderson, L. H., and C. S. Holling. 2002. Panarchy: understanding transformations in human and natural systems. Island Press, Washington, D.C., USA.

Guthman, J. 2008. Neoliberalism and the making of food politics in California. Geoforum 39(3):1171-1183. http://dx.doi. org/10.1016/j.geoforum.2006.09.002

Hadfield, J. D. 2010. MCMC methods for multi-response generalized linear mixed models: the MCMCglmm R package. Journal of Statistical Software 33(2):1-22. http://dx.doi. org/10.18637/jss.v033.i02

Halfacree, K. 2001. Going 'back-to-the-land' again: extending the scope of counterurbanisation. Espace, Populations, Sociétés 19(1):161-170. http://dx.doi.org/10.3406/espos.2001.1984

Hamilton, C., and E. Mail. 2003. Downshifting in Australia: a seachange in the pursuit of happiness. Australia Institute, Canberra, Australia.

Hicks, D. A. 1997. The inequality-adjusted human development index: a constructive proposal. World Development 25 (8):1283-1298. http://dx.doi.org/10.1016/s0305-750x(97)00034-x

Hines, J. M., H. R. Hungerford, and A. N. Tomera. 1987. Analysis and synthesis of research on responsible environmental behavior: a meta-analysis. Journal of Environmental Education 18(2):1-8. http://dx.doi.org/10.1080/00958964.1987.9943482

Hobbs, R. J., L. M. Hallett, P. R. Ehrlich, and H. A. Mooney. 2011. Intervention ecology: applying ecological science in the twenty-first century. BioScience 61:442-450. http://dx.doi. org/10.1525/bio.2011.61.6.6

Holmgren, D. 2002. Permaculture: principles \& pathways beyond sustainability. Holmgren Design Services, Hepburn, Victoria, Australia.

Ingram, J., D. Maye, J. Kirwan, N. Curry, and K. Kubinakova. 2014. Learning in the permaculture community of practice in England: an analysis of the relationship between core practices and boundary processes. Journal of Agricultural Education and Extension 20(3):275-290. http://dx.doi.org/10.1080/1389224x.2014.887756

Johnson, C. Y., J. M. Bowker, and H. K. Cordell. 2004. Ethnic variation in environmental belief and behavior: an examination of the new ecological paradigm in a social psychological context.
Environment and Behavior 36(2):157-186. http://dx.doi. org/10.1177/0013916503251478

Kaiser, H. F. 1974. An index of factorial simplicity. Psychometrika 39(1):31-36. http://dx.doi.org/10.1007/bf02291575

Kalof, L., T. Dietz, G. A. Guagnano, and P. C. Stern. 2002. Race, gender and environmentalism: the atypical values and beliefs of white men. Race, Gender \& Class 9(2):112-130.

Kemmelmeier, M., G. Król, and Y. H. Kim. 2002. Values, economics, and proenvironmental attitudes in 22 societies. CrossCultural Research 36(3):256-285. http://dx.doi.org/10.1177/1069$\underline{7102036003004}$

Kirk, R. E. 1996. Practical significance: a concept whose time has come. Educational and Psychological Measurement 56(5):746759. http://dx.doi.org/10.1177/0013164496056005002

Kitts, J. A. 2000. Mobilizing in black boxes: social networks and participation in social movement organizations. Mobilization: An International Quarterly 5(2):241-257.

Koch, G. G., and D. B. Gillings. 2004. Inference, design-based vs. model-based. Encyclopedia of Statistical Sciences. John Wiley \& Sons, West Sussex, UK. http://dx.doi.org/10.1002/0471667196. ess 1235

Kray, L. J., and L. Babcock. 2006. Gender in negotiations: a motivated social cognitive analysis. Negotiation Theory and Research 11:203-224.

Lawhon, M., and J. T. Murphy. 2012. Socio-technical regimes and sustainability transitions: insights from political ecology. Progress in Human Geography 36(3):354-378. http://dx.doi. org/10.1177/0309132511427960

Leach, M., J. Rockström, P. Raskin, I. Scoones, A. C. Stirling, A. Smith, J. Thompson, E. Millstone, A. Ely, E. Arond, C. Folke, and P. Olsson. 2012. Transforming innovation for sustainability. Ecology and Society 17(2):11. http://dx.doi.org/10.5751/ es-04933-170211

Lefroy, E. C. 2009. Agroforestry and the functional mimicry of natural ecosystems. Pages 23-35 in I. Nyberg, B. George, R. Reid, editors. Agroforestry for natural resource management. CSIRO Publishing, Melbourne, Australia.

Lewis, T. 2014. 'One city block at a time': researching and cultivating green transformations. International Journal of Cultural Studies 18(3):347-363. http://dx.doi.org/10.1177/13678$\underline{77913513694}$

Li, T., and K. Wehr. 2007. The validity of the factor structure of the general social survey environmentalism scales across gender and ethnicity in the United States. Organization \& Environment 20(3):367-385. http://dx.doi.org/10.1177/1086026607306461

Lockie, S. 1995. Rural gender relations and landcare. Pages 75-88 in With a rural focus. Centre for Rural Social Research, Charles Sturt University, Wagga Wagga, New South Wales, Australia.

MacGregor, S. 2002. Bright new vision or same old story? Looking for gender justice in the eco-city. Pages 71-92 in C. Andrew, K. A. Graham, and S. D. Phillips, editors. Urban affairs: back on the policy agenda. McGill-Queen's University Press, Montréal, Québec, Canada. 
Maher, J. M., J. C. Markey, and D. Ebert-May. 2013. The other half of the story: effect size analysis in quantitative research. $C B E$ Life Sciences Education 12(3):345-351. http://dx.doi.org/10.1187/ cbe.13-04-0082

McCarthy, J., and S. Prudham. 2004. Neoliberal nature and the nature of neoliberalism. Geoforum 35:275-283. http://dx.doi. org/10.1016/j.geoforum.2003.07.003

McFarlane, B. L., and P. C. Boxall. 2003. The role of social psychological and social structural variables in environmental activism: an example of the forest sector. Journal of Environmental Psychology 23(1):79-87. http://dx.doi.org/10.1016/s0272-4944 (02)00080-4

Meigs, B. L. 2004. Tackling children's food insecurity in the highlands of Guatemala with schoolyard permaculture gardens. Cornell University, Ithaca, New York, USA.

Menegat, R. 2002. Participatory democracy and sustainable development: integrated urban environmental management in Porto Alegre, Brazil. Environment and Urbanization 14 (2):181-206. http://dx.doi.org/10.1177/095624780201400215

Mohai, P. 1992. Men, women, and the environment: an examination of the gender gap in environmental concern and activism. Society \& Natural Resources 5(1):1-19. http://dx.doi. org/10.1080/08941929209380772

Mohan, G., and K. Stokke. 2000. Participatory development and empowerment: the dangers of localism. Third World Quarterly 21 (2):247-268. http://dx.doi.org/10.1080/01436590050004346

Mollison, B. 1988. Permaculture: a designer's manual. Tagari, Tasmania, Australia.

Mollison, B. 1997. Travels in dreams: an autobiography. Tagari, Tasmania, Australia.

Mostafa, M. M. 2013. Wealth, post-materialism and consumers' pro-environmental intentions: a multilevel analysis across 25 nations. Sustainable Development 21(6):385-399. http://dx.doi. org/10.1002/sd.517

Nawrotzki, R. J. 2012. The politics of environmental concern: a cross-national analysis. Organization \& Environment 25 (3):286-307. http://dx.doi.org/10.1177/1086026612456535

Newell, S., J. A. Swan, and R. D. Galliers. 2000. A knowledgefocused perspective on the diffusion and adoption of complex information technologies: the BPR example. Information Systems Journal 10(3):239-259. http://dx.doi.org/10.1046/j.1365-2575.2000.00079. $\underline{\mathrm{x}}$

Nudds, T. D. 1999. Adaptive management and the conservation of biodiversity. Island Press, Washington, D.C., USA.

O'Brien, K. 2012. Global environmental change II: from adaptation to deliberate transformation. Progress in Human Geography 36(5):667-676. http://dx.doi.org/10.1177/0309132511425767

Olson-Ramanujan, K. 2013. Women in permaculture. Permaculture Activist (88).

O’Shaughnessy, S., and E. H. Kennedy. 2010. Relational activism: reimagining women's environmental work as cultural change. Canadian Journal of Sociology 35(4):551-572.
Pachucki, M. A., S. Pendergrass, and M. Lamont. 2007. Boundary processes: recent theoretical developments and new contributions. Poetics 35(6):331-351. http://dx.doi.org/10.1016/j. poetic.2007.10.001

Pálsson, G. 1996. Human-environmental relations: Orientalism, communalism, paternalism. Pages 63-81 in P. Descola and G. Pálsson, editors. Nature and society. Routledge, London, UK.

Pansera, M., and R. Owen. 2014. Eco-innovation at the "bottom of the pyramid." Pages 293-313 in D. A. Vazquez-Brust, J. Sarkis, and J. J. Cordeiro, editors. Collaboration for sustainability and innovation: a role for sustainability driven by the global south? Springer, Dordrecht, The Netherlands. http://dx.doi. org/10.1007/978-94-007-7633-3_15

Parker, J. D., and M. H. McDonough. 1999. Environmentalism of African Americans: an analysis of the subculture and barriers theories. Environment and Behavior 31(2):155-177. http://dx.doi. org/10.1177/00139169921972047

Paschen, J.-A., and R. Ison. 2014. Narrative research in climate change adaptation - exploring a complementary paradigm for research and governance. Research Policy 43(6):1083-1092. http:// dx.doi.org/10.1016/j.respol.2013.12.006

Philippe, D., and P. Bansal. 2013. Embedding environmental actions in time and space: the evolution of sustainability narratives. Academy of Management Proceedings 2013(1):14098. http://dx.doi.org/10.5465/ambpp.2013.151

$\mathrm{R}$ Core Team. 2015. The $R$ project for statistical computing. $\mathrm{R}$ Foundation for Statistical Computing, Vienna, Austria. [online URL: https://www.R-project.org/

Raîche, G., T. A. Walls, D. Magis, M. Riopel, and J.-G. Blais. 2013. Non-graphical solutions for Cattell's scree test. Methodology: European Journal of Research Methods for the Behavioral and Social Sciences 9(1):23-29. http://dx.doi. org/10.1027/1614-2241/a000051

Rainey, S. A., and G. S. Johnson. 2009. Grassroots activism: an exploration of women of color's role in the environmental justice movement. Race, Gender \& Class 16(3/4):144-173.

Revelle, W. 2012. Psych: procedures for psychological, psychometric, and personality research. $\mathrm{R}$ package version 1(1). Northwestern University, Evanston, Illinois, USA.

Scherr, S. J., and J. A. McNeely. 2008. Biodiversity conservation and agricultural sustainability: towards a new paradigm of 'ecoagriculture' landscapes. Philosophical Transactions of the Royal Society B: Biological Sciences 363:477-494. http://dx.doi. org/10.1098/rstb.2007.2165

Schonlau, M., R. D. Fricker, and M. N. Elliott. 2002. Choosing among the various types of internet surveys. Pages 33-40 in Conducting research surveys via e-mail and the web. RAND Corporation, Santa Monica, California, USA.

Sen, A., and S. Anand. 1994. Human development index: methodology and measurement. Human Development Occasional Papers (1992-2007), Human Development Report Office (HDRO), United Nations Development Programme, New York, New York, USA. 
Seyfang, G. 2007. Growing sustainable consumption communities: the case of local organic food networks. International Journal of Sociology and Social Policy 27 (3/4):120-134. http://dx.doi.org/10.1108/01443330710741066

Seyfang, G., and A. Haxeltine. 2012. Growing grassroots innovations: exploring the role of community-based initiatives in governing sustainable energy transitions. Environment and Planning C: Government and Policy 30(3):381-400. http://dx.doi. org/10.1068/c10222

Seyfang, G., and A. Smith. 2007. Grassroots innovations for sustainable development: towards a new research and policy agenda. Environmental Politics 16(4):584-603. http://dx.doi. org/10.1080/09644010701419121

Smith, A. 2006. Green niches in sustainable development: the case of organic food in the United Kingdom. Environment and Planning C: Government and Policy 24(3):439-458. http://dx.doi. org/10.1068/c0514j

Smith, A., M. Fressoli, and H. Thomas. 2014. Grassroots innovation movements: challenges and contributions. Journal of Cleaner Production 63:114-124. http://dx.doi.org/10.1016/j. jclepro.2012.12.025

Smith, A., and A. Stirling. 2010. The politics of social-ecological resilience and sustainable socio-technical transitions. Ecology and Society 15(1):11. [online] URL: http://www.ecologyandsociety. org/vol15/iss1/art11/

Smith, C. 2002. Learning for the environment: an examination of personal empowerment through learning permaculture. PostScript 3(1):12-25.

Soares, A. 2003. Instituto de Permacultura e Ecovilas do Cerrado: a permaculture model for sustainable land use and appropriate technologies in central Brazil. The Change Agency, Newcastle, Australia. [online] URL: http://www.thechangeagency.org/wpcontent/uploads/2014/02/CaseStudy PermacultureIPEC.pdf

Sterba, S. K. 2009. Alternative model-based and design-based frameworks for inference from samples to populations: from polarization to integration. Multivariate Behavioral Research 44 (6):711-740. http://dx.doi.org/10.1080/00273170903333574

Strongman, L. 2012. Modern nature: essays in environmental communication. Universal-Publishers, Boca Raton, Florida, USA.

Sue, D. W. 2004. Whiteness and ethnocentric monoculturalism making the "invisible" visible. American Psychologist 59 (8):761-769. http://dx.doi.org/10.1037/0003-066x.59.8.761

Suh, J. 2014a. Towards sustainable agricultural stewardship: evolution and future directions of the permaculture concept. Environmental Values 23(1):75-98. http://dx.doi.org/10.3197/096$\underline{327114 X 13851122269089}$

Suh, J. 2014b. Theory and reality of integrated rice-duck farming in Asian developing countries: a systematic review and SWOT analysis. Agricultural Systems 125:74-81. http://dx.doi.org/10.1016/ j.agsy.2013.11.003

Taylor, D. E. 1997. American environmentalism: the role of race, class and gender in shaping activism 1820-1995. Race, Gender \& Class 5(1):16-62.
Terui, R. 2000. Development from within: the Jajarkot Permaculture Program in Nepal. University of WisconsinMadison, Madison, USA.

Tindall, D. B., S. Davies, and C. Mauboulès. 2003. Activism and conservation behavior in an environmental movement: the contradictory effects of gender. Society \& Natural Resources 16 (10):909-932. http://dx.doi.org/10.1080/716100620

Toensmeier, E., and J. Bates. 2013. Paradise lot: two plant geeks, one-tenth of an acre, and the making of an edible garden oasis in the city. Chelsea Green Publishing Company, White River Junction, Vermont, USA.

Trapese Collective. 2008. The rocky road to a real transition: the transition towns movement and what it means for social change. Trapese Collective, UK. [online] URL: http://trapese. clearerchannel.org/resources/rocky-road-a5-web.pdf

Uzzell, D. L. 2000. The psycho-spatial dimension of global environmental problems. Journal of Environmental Psychology 20 (4):307-318. http://dx.doi.org/10.1006/jevp.2000.0175

van Buuren, S., and K. Groothuis-Oudshoorn. 2011. MICE: Multivariate imputation by chained equations in R. Journal of Statistical Software 45(3):1-67. http://dx.doi.org/10.18637/jss. v045.i03

Ventura, A. C., and J. C. S. Andrade. 2011. Polyculture in the semi-arid regions of Brazil. Field Actions Science Reports Special Issue 3.

Verba, S., K. L. Schlozman, and H. E. Brady. 1995. Voice and equality: civic voluntarism in American politics. Harvard University Press, Cambridge, Massachusetts, USA.

Villamor, G. B., M. van Noordwijk, U. Djanibekov, M. E. ChiongJavier, and D. Catacutan. 2014. Gender differences in land-use decisions: shaping multifunctional landscapes? Current Opinion in Environmental Sustainability 6:128-133. http://dx.doi. org/10.1016/i.cosust.2013.11.015

Xiao, C., and A. M. McCright. 2014. A test of the biographical availability argument for gender differences in environmental behaviors. Environment and Behavior 46(2):241-263. http://dx.doi. org/10.1177/0013916512453991

Yuen, E., M. Anda, K. Mathew, and G. Ho. 2001. Water harvesting techniques for small communities in arid areas. Water Science \& Technology 44:189-194. 